\title{
LEVEL II SCOUR ANALYSIS FOR BRIDGE 39 (LOWETH00080039) on TOWN HIGHWAY 8, crossing POTTER BROOK, LOWELL, VERMONT
}

U.S. Geological Survey Open-File Report 97-629

Prepared in cooperation with

VERMONT AGENCY OF TRANSPORTATION and

FEDERAL HIGHWAY ADMINISTRATION 
LEVEL II SCOUR ANALYSIS FOR

BRIDGE 39 (LOWETH00080039) on

TOWN HIGHWAY 8, crossing

POTTER BROOK,

LOWELL, VERMONT

By ERICK M. BOEHMLER and JAMES R. DEGNAN

U.S. Geological Survey

Open-File Report 97-629

Prepared in cooperation with

VERMONT AGENCY OF TRANSPORTATION

and

FEDERAL HIGHWAY ADMINISTRATION 


\title{
U.S. DEPARTMENT OF THE INTERIOR BRUCE BABBITT, Secretary
}

\author{
U.S. GEOLOGICAL SURVEY \\ Gordon P. Eaton, Director
}

For additional information write to:

District Chief

U.S. Geological Survey 361 Commerce Way

Pembroke, NH 03275-3718
Copies of this report may be purchased from:

U.S. Geological Survey

Branch of Information Services

Open-File Reports Unit

Box 25286

Denver, CO 80225-0286 


\section{CONTENTS}

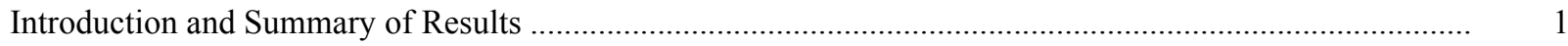

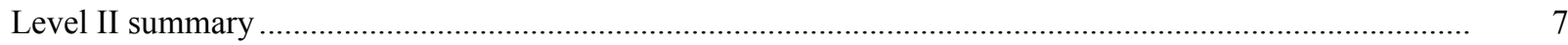

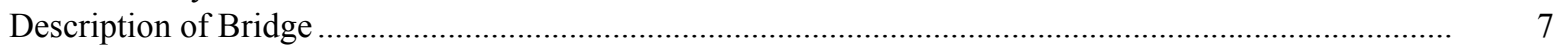

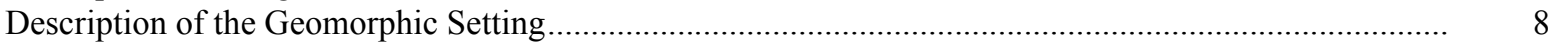

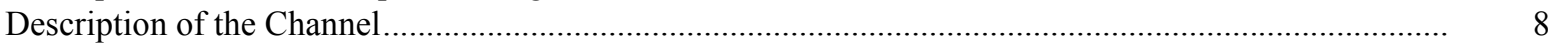

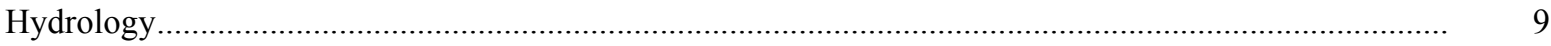

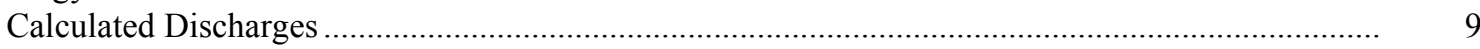

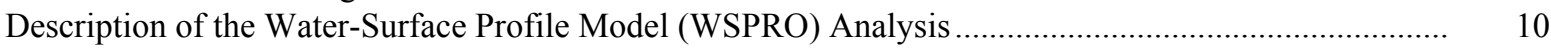

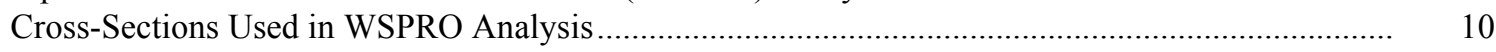

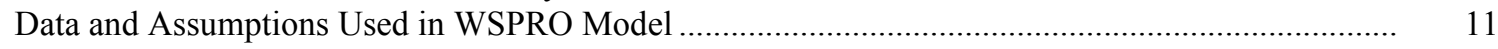

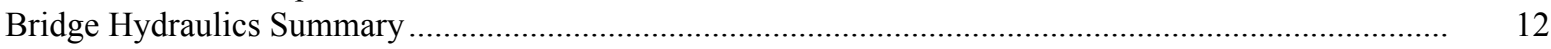

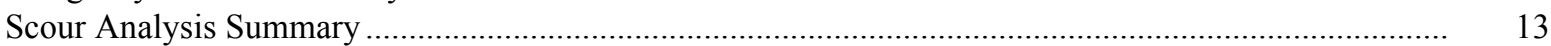

Special Conditions or Assumptions Made in Scour Analysis ...................................................... 13

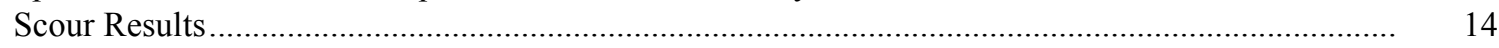

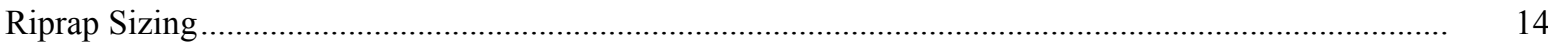

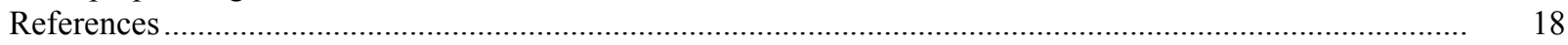

Appendixes:

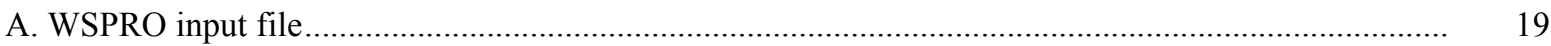

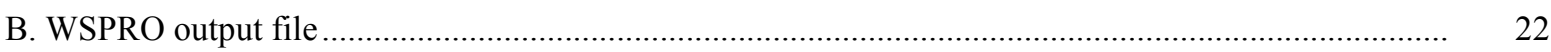

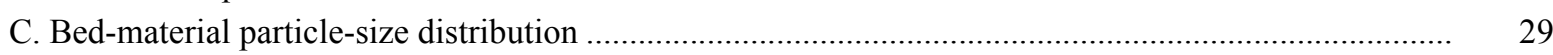

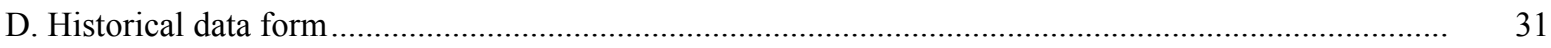

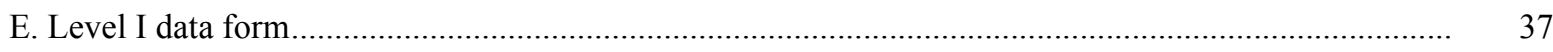

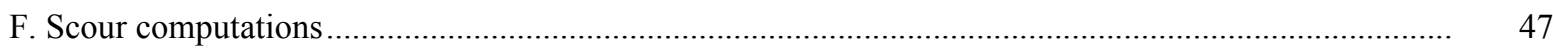

\section{FIGURES}

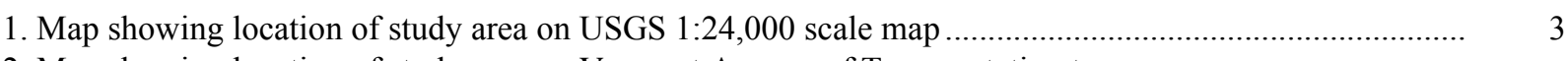

2. Map showing location of study area on Vermont Agency of Transportation town
highway map

3. Structure LOWETH00080039 viewed from upstream (June 15, 1995) .................................................. 5

4. Downstream channel viewed from structure LOWETH00080039 (June 15, 1995) ............................... 5

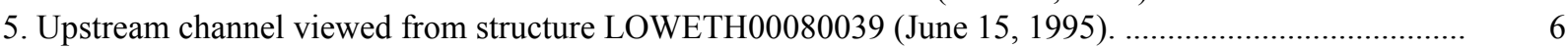

6. Structure LOWETH00080039 viewed from downstream (June 15, 1995)........................................ 6

7. Water-surface profiles for the 100- and 500-year discharges at structure

LOWETH00080039 on Town Highway 8, crossing Potter Brook,

Lowell, Vermont.

8. Scour elevations for the 100- and 500-year discharges at structure

LOWETH00080039 on Town Highway 8, crossing Potter Brook,

Lowell, Vermont.

\section{TABLES}

1. Remaining footing/pile depth at abutments for the 100-year discharge at structure

LOWETH00080039 on Town Highway 8, crossing Potter Brook,

Lowell, Vermont......

2. Remaining footing/pile depth at abutments for the 500-year discharge at structure

LOWETH00080039 on Town Highway 8, crossing Potter Brook,

Lowell, Vermont 


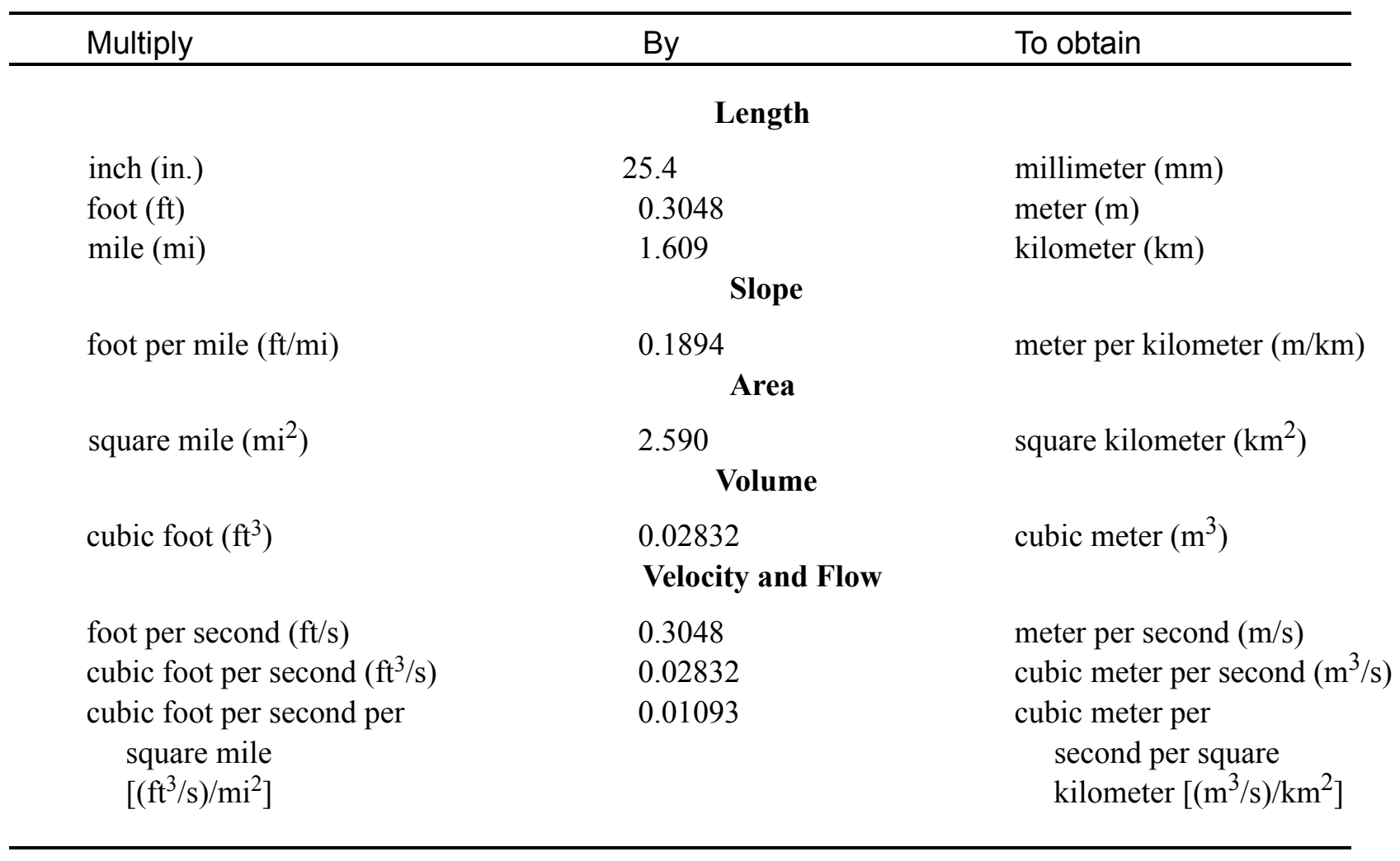

\section{OTHER ABBREVIATIONS}

$\begin{array}{lrlr}\mathrm{BF} & \text { bank full } & \text { LWW } & \text { left wingwall } \\ \mathrm{cfs} & \text { cubic feet per second } & \text { MC } & \text { main channel } \\ \mathrm{D}_{50} & \text { median diameter of bed material } & \text { RAB } & \text { right abutment } \\ \mathrm{DS} & \text { downstream } & \text { RABUT } & \text { face of right abutment } \\ \mathrm{elev} & \text { elevation } & \text { RB } & \text { right bank } \\ \mathrm{f} / \mathrm{p} & \text { flood plain } & \text { ROB } & \text { right overbank } \\ \mathrm{ft}^{2} & \text { square feet } & \text { RWW } & \text { right wingwall } \\ \mathrm{ft} / \mathrm{ft} & \text { feet per foot } & \text { TH } & \text { town highway } \\ \mathrm{JCT} & \text { junction } & \text { UB } & \text { under bridge } \\ \mathrm{LAB} & \text { left abutment } & \text { US } & \text { upstream } \\ \mathrm{LABUT} & \text { face of left abutment } & \text { USGS } & \text { United States Geological Survey } \\ \mathrm{LB} & \text { left bank } & \text { VTAOT Vermont Agency of Transportation } \\ \mathrm{LOB} & \text { left overbank } & \text { WSPRO } & \text { water-surface profile model }\end{array}$

In this report, the words "right" and "left" refer to directions that would be reported by an observer facing downstream. Sea level: In this report, "sea level" refers to the National Geodetic Vertical Datum of 1929-- a geodetic datum derived from a general adjustment of the first-order level nets of the United States and Canada, formerly called Sea Level Datum of 1929.

In the appendices, the above abbreviations may be combined. For example, USLB would represent upstream left bank. 


\title{
LEVEL II SCOUR ANALYSIS FOR BRIDGE 39 (LOWETH00080039) ON TOWN HIGHWAY 8, CROSSING POTTER BROOK, LOWELL, VERMONT
}

\author{
By Erick M. Boehmler and James R. Degnan
}

\section{INTRODUCTION AND SUMMARY OF RESULTS}

This report provides the results of a detailed Level II analysis of scour potential at structure LOWETH00080039 on Town Highway 8 crossing Potter Brook, Lowell, Vermont (figures $1-8)$. A Level II study is a basic engineering analysis of the site, including a quantitative analysis of stream stability and scour (U.S. Department of Transportation, 1993). Results of a Level I scour investigation also are included in Appendix E of this report. A Level I investigation provides a qualitative geomorphic characterization of the study site. Information on the bridge, gleaned from Vermont Agency of Transportation (VTAOT) files, was compiled prior to conducting Level I and Level II analyses and is found in Appendix D.

The site is in the Green Mountain section of the New England physiographic province in north-central Vermont. The $4.69-\mathrm{mi}^{2}$ drainage area is in a predominantly rural and forested basin. In the vicinity of the study site, the surface cover consists of shrub and brushland, except for the left overbank upstream which is forest.

In the study area, Potter Brook has a sinuous channel with a slope of approximately 0.004 $\mathrm{ft} / \mathrm{ft}$, an average channel top width of 34 feet and an average bank height of $3 \mathrm{ft}$. The predominant channel bed materials are gravel and sand with a median grain size $\left(\mathrm{D}_{50}\right)$ of $18.7 \mathrm{~mm}(0.0613 \mathrm{ft})$. The geomorphic assessment at the time of the Level I and Level II site visit on June 15, 1995, indicated that the reach was laterally unstable. This assessment of the reach was primarily due to the meandering of the channel with cut-banks and narrow point bars and the fine bank and bed material near the site.

The Town Highway 8 crossing of Potter Brook is a 23-ft-long, one-lane bridge consisting of one 21-foot steel-beam span (Vermont Agency of Transportation, written communication, March 7, 1995). The bridge is supported by vertical, concrete abutments with wingwalls. The channel is skewed approximately 20 degrees to the opening while the opening-skew-toroadway is zero degrees.

A scour hole 2.0 feet deeper than the mean thalweg depth was observed along the left abutment during the Level I assessment. There were no scour protection measures evident at the site. Additional details describing conditions at the site are included in the Level II Summary and Appendices D and E. 
Scour depths and recommended rock rip-rap sizes were computed using the general guidelines described in Hydraulic Engineering Circular 18 (Richardson and others, 1995). Total scour at a highway crossing is comprised of three components: 1) long-term streambed degradation; 2) contraction scour (due to accelerated flow caused by a reduction in flow area at a bridge) and; 3) local scour (caused by accelerated flow around piers and abutments). Total scour is the sum of the three components. Equations are available to compute depths for contraction and local scour and a summary of the results of these computations follows.

Contraction scour for all modelled flows ranged from 0.0 to $0.3 \mathrm{ft}$. The worst-case contraction scour occurred at the 500-year discharge. Abutment scour ranged from 1.8 to 5.5 feet. The worst-case abutment scour occurred at the 100-year discharge. Additional information on scour depths and depths to armoring are included in the section titled "Scour Results". Scoured-streambed elevations, based on the calculated scour depths, are presented in tables 1 and 2. A cross-section of the scour computed at the bridge is presented in figure 8. Scour depths were calculated assuming an infinite depth of erosive material and a homogeneous particle-size distribution.

It is generally accepted that the Froehlich equation (abutment scour) gives "excessively conservative estimates of scour depths" (Richardson and others, 1995, p. 47). Usually, computed scour depths are evaluated in combination with other information including (but not limited to) historical performance during flood events, the geomorphic stability assessment, existing scour protection measures, and the results of the hydraulic analyses. Therefore, scour depths adopted by VTAOT may differ from the computed values documented herein. 


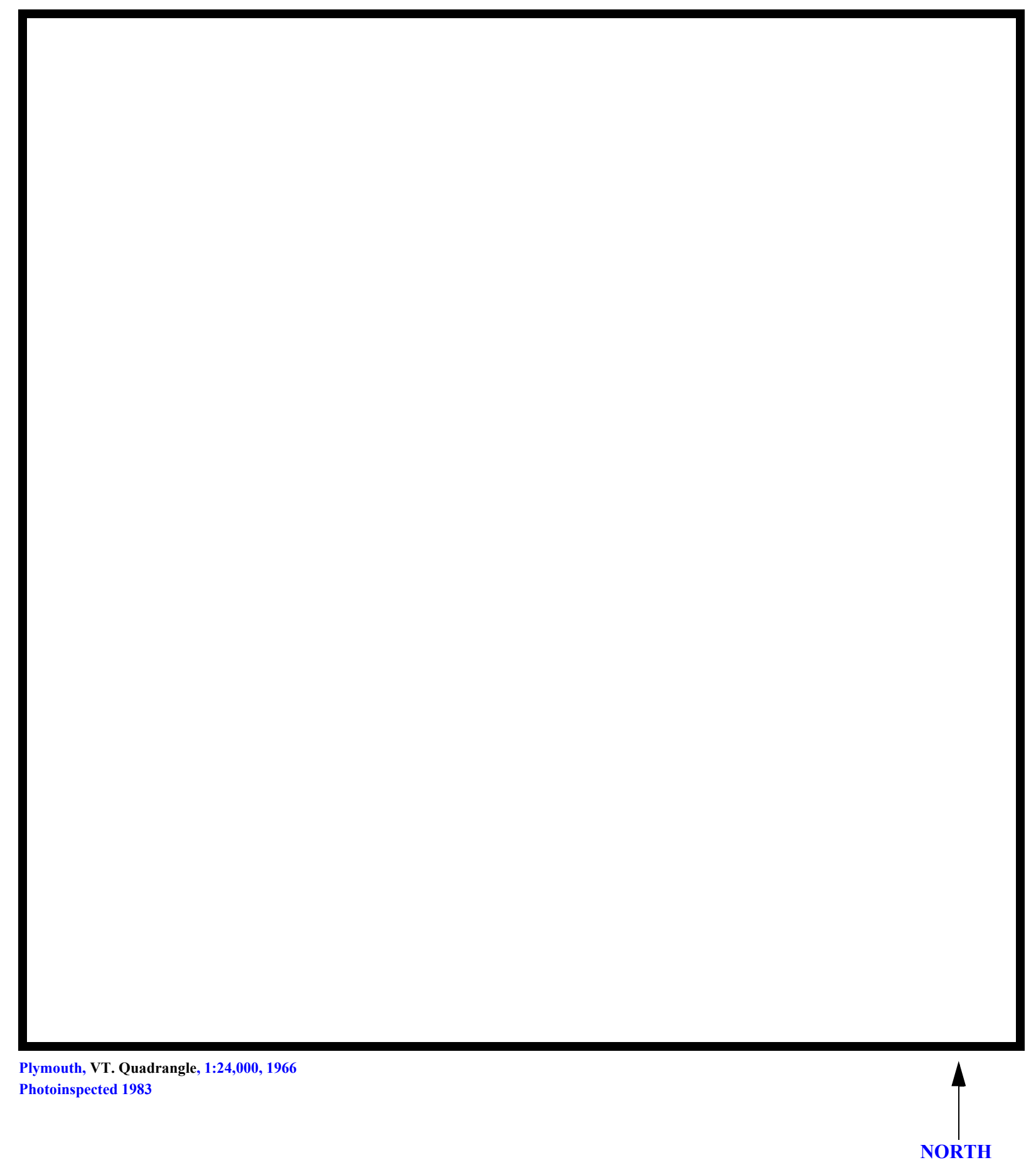

Figure 1. Location of study area on USGS 1:24,000 scale map. 
Figure 2. Location of study area on Vermont Agency of Transportation town highway map. 

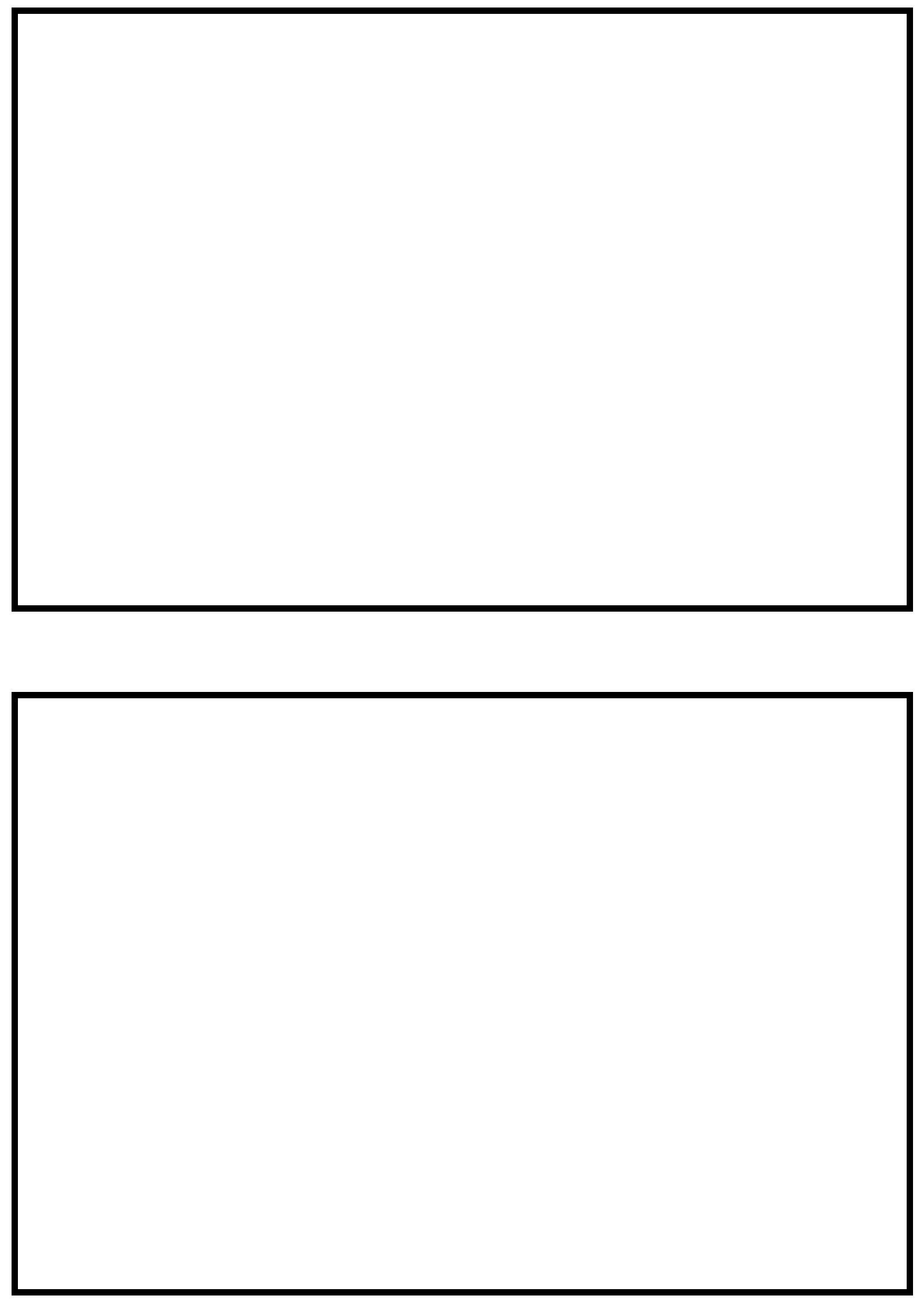

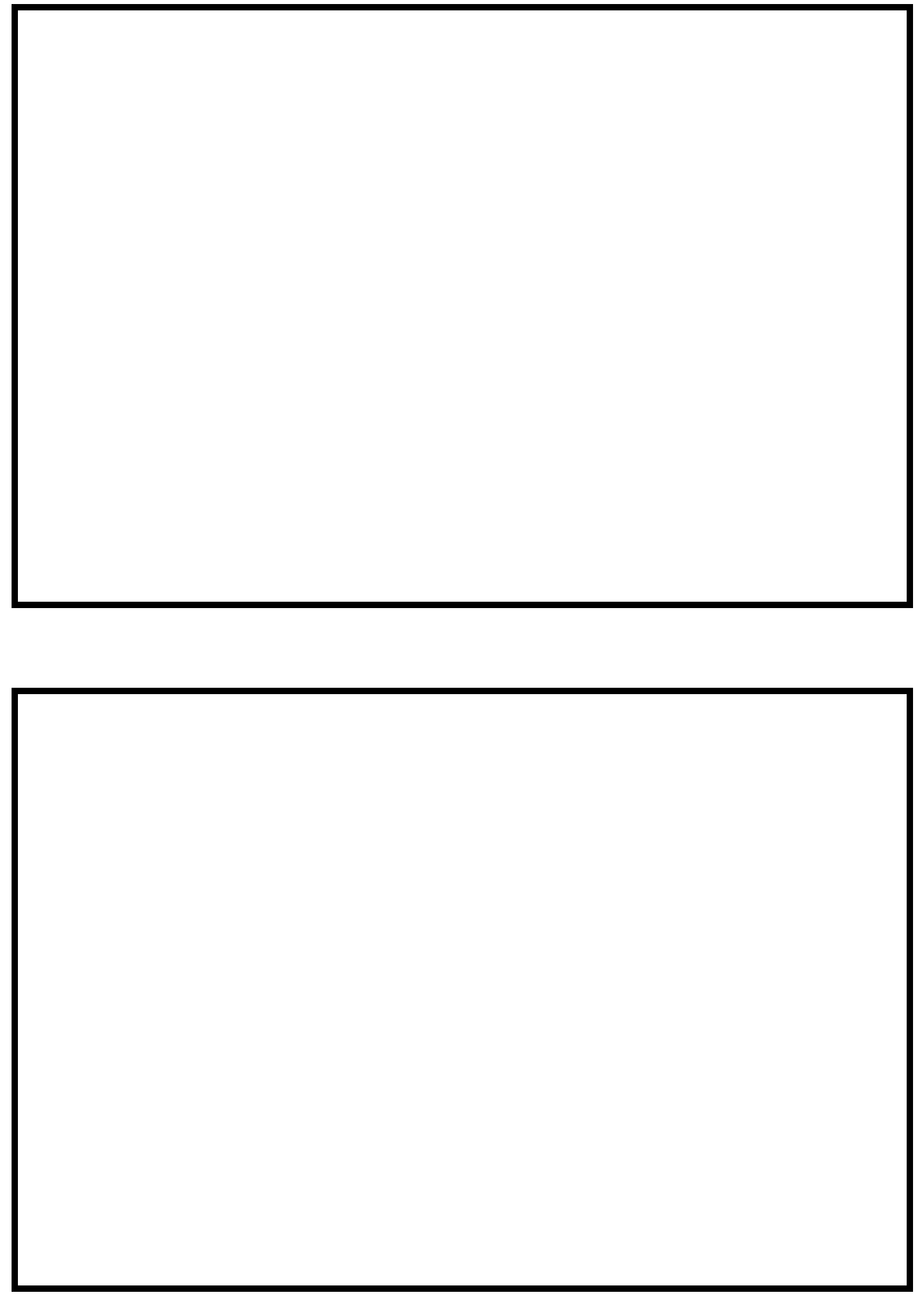


\section{LEVEL II SUMMARY}

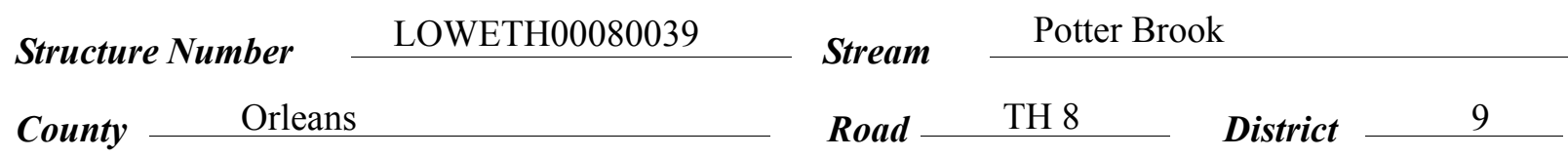

\section{Description of Bridge}

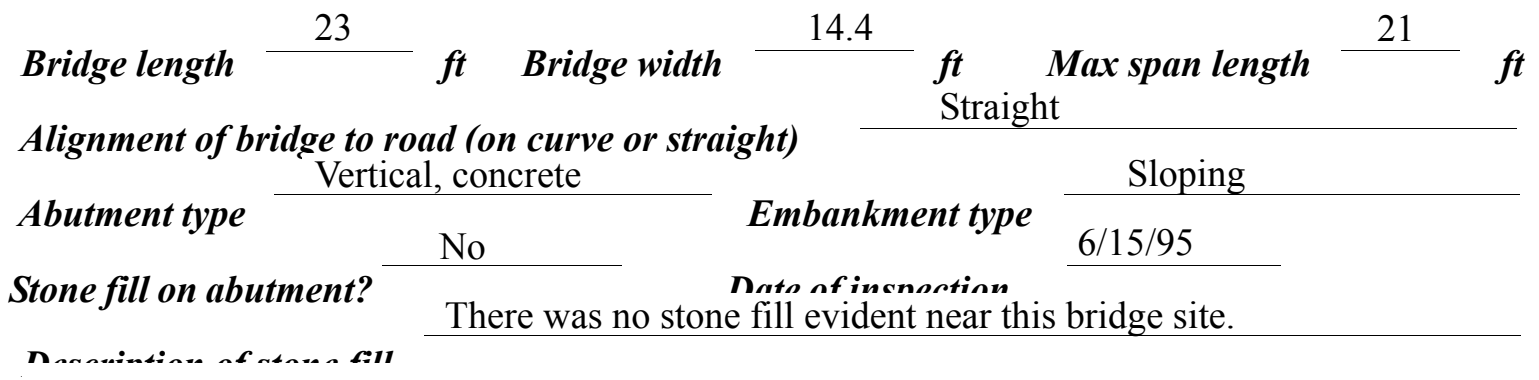

Abutments and wingwalls are concrete. There is a 2.0

foot deep scour hole along the left abutment.

Yes
Is bridge skewed to flood flow according to Yes 'survey? Angle

There is a moderate channel bend in the upstream reach. The scour hole has developed in the location where the flow impacts the left abutment.

Debris accumulation on bridge at time of Level I or Level II site visit:
Date of incnortion $6 / 15 / 95$

Level I

$$
6 / 15 / 95
$$

Level II

\section{Percent of rhominal blocked inortzontatly}

0
20

(1)

laterally unstable channel.

Potential for debris

None were evident on 6/15/95.

\section{Percent of allon.... blocked verticatty}

0

Dosrriho anv, fonturos noar ar at tho hridoo that mav, affort flow, (includo ahsorvation dato) 


\section{Description of the Geomorphic Setting}

General topography The channel is located in a moderate relief valley setting with irregular flood plains and moderately sloping valley walls on both sides.

Geomorphic conditions at bridge site: downstream (DS), upstream (US)

Date of inspection $\quad 6 / 15 / 95$

DS left: $\quad$ Moderately sloping bank and a wide flood plain.

DS right: $\quad$ Moderately sloping bank and a narrow flood plain.

US left: $\quad$ Moderately sloping bank and a narrow flood plain.

US right: $\quad$ Moderately sloping bank and a narrow flood plain.

\section{Description of the Channel}

\begin{tabular}{|c|c|c|c|c|}
\hline \multirow[b]{2}{*}{ Average top width } & 34 & \multirow[b]{2}{*}{ Average depth } & 3 & \multirow[b]{2}{*}{$f$} \\
\hline & $\stackrel{\boldsymbol{f t}}{\text { Gravel / Sand }}$ & & Sand & \\
\hline Predominant bed $m$ & & Bank material & Meander & \\
\hline
\end{tabular}

swampy with alluvial channel boundaries and narrow point bars.

$6 / 15 / 95$

Vegetative co 1 Shrubs and brush

DS left: $\quad$ Shrubs and brush

DS right: $\quad$ Trees and shrubs with some tall grass.

US left: $\quad$ Shrubs and brush.

US right: $\quad$ No

Do banks appear stable? On 6/15/95, the channel was noted as meandering and had many cutbanks with moderately eroding bank material and narrow point bars.
date of observatton.

None noted on

$6 / 15 / 95$.

Describe any obstructions in channel and date of observation. 


\title{
Hydrology
}

Drainage area $\stackrel{4.69}{\mathrm{mi}^{2}}$

Percentage of drainage area in physiographic provinces: (approximate)

Physiographic province/section

New England/Green Mountain
Percent of drainage area 100

\begin{abstract}
Is drainage area considered rural or urban?
Rural urbanization:

Describe any significant
\end{abstract}

Is there a USGS gage on the stream of interest? $\frac{\mathrm{No}}{--}$
USGS gage description

USGS gage number

Gage drainage area $\mathrm{mi}^{2}$

No

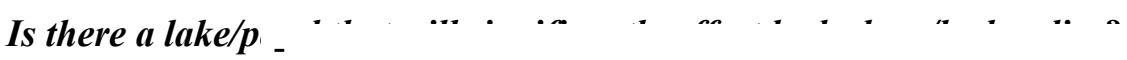

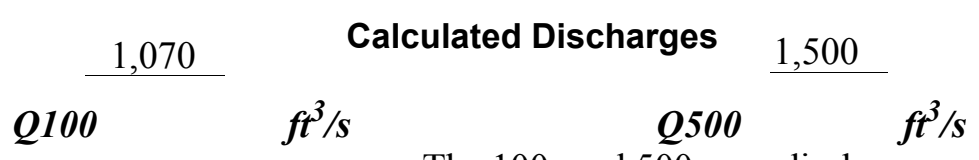

The 100- and 500-year discharges are based on a

drainage area relationship.[(4.69/2.22)exp 0.67] with bridge number 13 in Lowell. Bridge number 13 crosses Leclair Brook, a characteristically similar nearby watershed, and has flood frequency estimates available from the VTAOT database. The drainage area above bridge number 13 is 2.22 square miles. The computed discharges from this area relationship were within a range of discharges computed by use of empirical methods (Benson, 1962; FHWA, 1983; Johnson and Laraway, 1972; Johnson and Tasker, 1974; Potter, 1957; Talbot, 1887). 


\section{Description of the Water-Surface Profile Model (WSPRO) Analysis}

Datum for WSPRO analysis (USGS survey, sea level, VTAOT plans)

USGS survey

Datum tie between USGS survey and VTAOT plans

None

Description of reference marks used to determine USGS datum. $\quad$ RM1 is a nail at the

center point of a chiseled " $X$ " at the right end of the $4 \times 4$, wooden curb on the downstream side of the bridge deck (elev. 500.70 feet, arbitrary survey datum). RM2 is a nail at the center point

of a chiseled " $X$ " at the left end of the $4 \times 4$, wooden curb on the upstream side of the bridge deck (elev. 500.63 feet, arbitrary survey datum).

\section{Cross-Sections Used in WSPRO Analysis}

\begin{tabular}{cccl}
\hline${ }^{1}$ Cross-section & $\begin{array}{c}\text { Section } \\
\text { Reference } \\
\text { Distance } \\
(\text { SRD) } \text { in feet }\end{array}$ & $\begin{array}{c}{ }^{2} \text { Cross-section } \\
\text { development }\end{array}$ & \multicolumn{1}{c}{ Comments } \\
\hline EXIT1 & -23 & 1 & Exit section \\
FULLV & 0 & 2 & $\begin{array}{l}\text { Downstream Full-valley } \\
\text { section (Templated from } \\
\text { EXIT1) }\end{array}$ \\
BRIDG & 0 & 1 & $\begin{array}{l}\text { Bridge section } \\
\text { RDWAY }\end{array}$ \\
APPR1 & 8 & 1 & Road Grade section \\
\hline
\end{tabular}

${ }^{1}$ For location of cross-sections see plan-view sketch included with Level I field form, Appendix E. For more detail on how cross-sections were developed see WSPRO input file. 


\section{Data and Assumptions Used in WSPRO Model}

Hydraulic analyses of the reach were done by use of the Federal Highway Administration's WSPRO step-backwater computer program (Shearman and others, 1986, and Shearman, 1990). The analyses reported herein reflect conditions existing at the site at the time of the study. Furthermore, in the development of the model it was necessary to assume no accumulation of debris or ice at the site. Results of the hydraulic model are presented in the Bridge Hydraulic Summary, Appendix B, and figure 7.

Channel roughness factors (Manning's “ $n$ ”) used in the hydraulic model were estimated using field inspections at each cross section following the general guidelines described by Arcement and Schneider (1989). Final adjustments to the values were made during the modelling of the reach. Channel " $n$ " values for the reach ranged from 0.035 to 0.040 , and overbank " $n$ " values ranged from 0.055 to 0.10 .

Normal depth at the exit section (EXIT1) was assumed as the starting water surface. This depth was computed by use of the slope-conveyance method outlined in the user's manual for WSPRO (Shearman, 1990). The slope used was $0.0043 \mathrm{ft} / \mathrm{ft}$, which was estimated from surveyed thalweg points downstream of the site.

The approach section (APPR1) was surveyed one bridge length upstream of the upstream face as recommended by Shearman and others (1986). This location also provides a consistent method for determining scour variables. 


\section{Bridge Hydraulics Summary}

$\begin{array}{llll}\text { Average bridge embankment elevation } & 500.1 & f t \\ \text { Average low steel elevation } & 497.9 & \boldsymbol{f t}\end{array}$

100-year discharge $\quad 1,070 \quad \mathrm{ft}^{3} / \mathrm{s}$

Water-surface elevation in bridge opening $\quad 498.0 \quad f t$

Road overtopping? ___ Yes Discharge over road __ $439 \quad \mathrm{ft}^{3} / \mathrm{s}$

Area of flow in bridge opening $\quad 117 \quad \mathrm{ft}^{2}$

Average velocity in bridge opening $\quad 5.4 \quad \mathrm{ft} / \mathrm{s}$

Maximum WSPRO tube velocity at bridge $\quad 6.6 \mathrm{ft} / \mathrm{s}$

Water-surface elevation at Approach section with bridge 499.8

Water-surface elevation at Approach section without bridge $\quad \overline{499.2}$

Amount of backwater caused by bridge $\quad 0.6 \quad$ it

500-year discharge $\quad 1,500 \quad \mathrm{ft}^{3} / \mathrm{s}$

Water-surface elevation in bridge opening $\quad 498.0 \mathrm{ft}$

Road overtopping? ___ Yes Discharge over road __ $819 \quad \mathrm{ft}^{3} / \mathrm{s}$

Area of flow in bridge opening $\quad 117 \quad \mathrm{ft}^{2}$

Average velocity in bridge opening $5.7 \mathrm{ft} / \mathrm{s}$

Maximum WSPRO tube velocity at bridge 7.1 _s

Water-surface elevation at Approach section with bridge 500.1

Water-surface elevation at Approach section without bridge $\quad 499.4$

Amount of backwater caused by bridge $\quad 0.7$.t

Incipient overtopping discharge $\quad 590 \quad \mathrm{ft}^{3} / \mathrm{s}$

Water-surface elevation in bridge opening $498.0 \quad t$

Area of flow in bridge opening

Average velocity in bridge opening

$117 \quad \mathrm{ft}^{2}$

Maximum WSPRO tube velocity at bridge $\quad 6.2 \mathrm{ft} / \mathrm{s}$

Water-surface elevation at Approach section with bridge

Water-surface elevation at Approach section without bridge

498.8

Amount of backwater caused by bridge $\quad 0.2$, t 


\section{Scour Analysis Summary}

\section{Special Conditions or Assumptions Made in Scour Analysis}

Scour depths were computed using the general guidelines described in Hydraulic Engineering Circular 18 (Richardson and others, 1995). Scour depths were calculated assuming an infinite depth of erosive material and a homogeneous particle-size distribution. The results of the scour analysis are presented in tables 1 and 2 and a graph of the scour depths is presented in figure 8 .

At this site, the modeled discharges resulted in submerged orifice flow. Contraction scour at bridges with orifice flow is best estimated by use of the Chang pressure-flow scour equation (oral communication, J. Sterling Jones, October 4, 1996). Thus, contraction scour was computed by use of the Chang equation (Richardson and others, 1995, p. 145-146). Results of this analysis are presented in figure 8 and tables 1 and 2. Additional estimates of contraction scour also were computed by use of Laursen's clear-water scour equation (Richardson and others, 1995, p. 32, equation 20) and the Umbrell equation (Richardson and others, 1995,

p. 144). Results from these equations are presented in Appendix F.

Abutment scour was computed by use of the HIRE equation (Richardson and others, 1995, p. 49, equation 29) for most discharges because the HIRE equation is recommended when the length to depth ratio of the embankment blocking flow exceeds 25. Variables for the HIRE equation include the Froude number of the flow approaching the embankments, the length of the embankment blocking flow, and the depth of flow approaching the embankment less any roadway overtopping.

Abutment scour for the left abutment at the incipient overtopping discharge was computed by use of the Froehlich equation (Richardson and others, 1995, p. 48, equation 28). Variables for the Froehlich equation are defined the same as those defined for the HIRE abutment-scour equation. 


\section{Scour Results}

$$
\text { 100-yr discharge 500-yr discharge }
$$

Contraction scour:

Main channel

Live-bed scour

Clear-water scour

Depth to armoring

Left overbank

Right overbank

Local scour:

Abutment scour

Left abutment

Right abutment

Pier scour

Pier 1

Pier 2

Pier 3
(Scour depths in feet) discharge

Incipient overtopping

(Scour depths in feet)

(1)

\begin{tabular}{cccc}
-- & -- & -- \\
0.0 & & 0.3 & 0.0 \\
$0.3^{-}$ & & $0.5^{-}$ & $0.2^{-}$ \\
-- & -- & -- \\
-- & -- & -- \\
\hline
\end{tabular}

5.5

$3.0-$
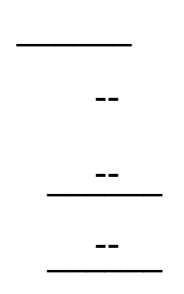

$\longrightarrow$

\section{2}

3.3-
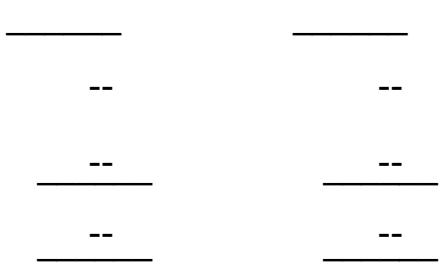

4.9

1.8

\section{Riprap Sizing}

Incipient overtopping 100-yr discharge 500-yrdischarge discharge

Abutments:

Left abutment

Right abutment

Piers:

Pier 1

Pier 2

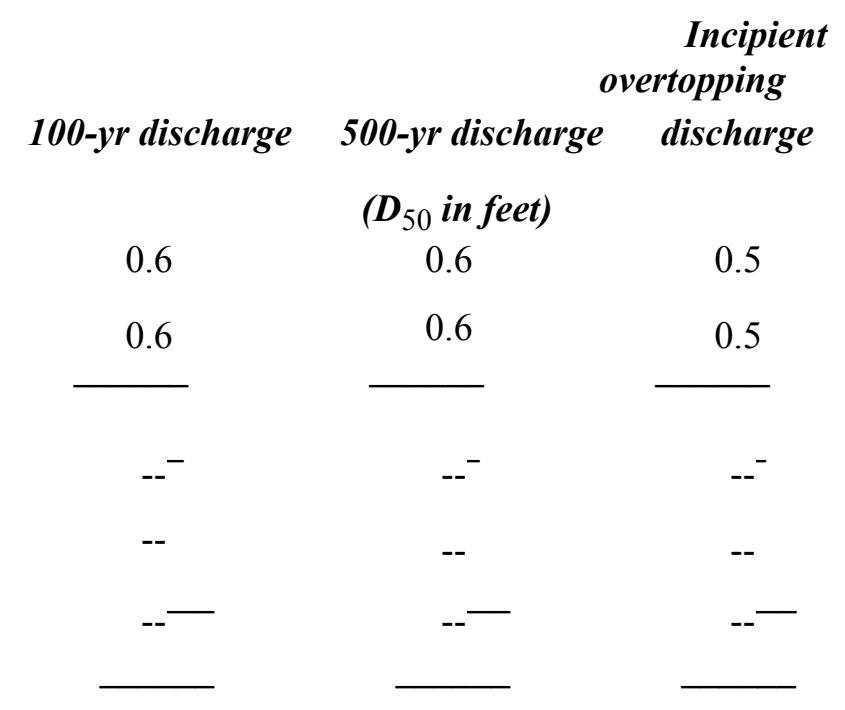




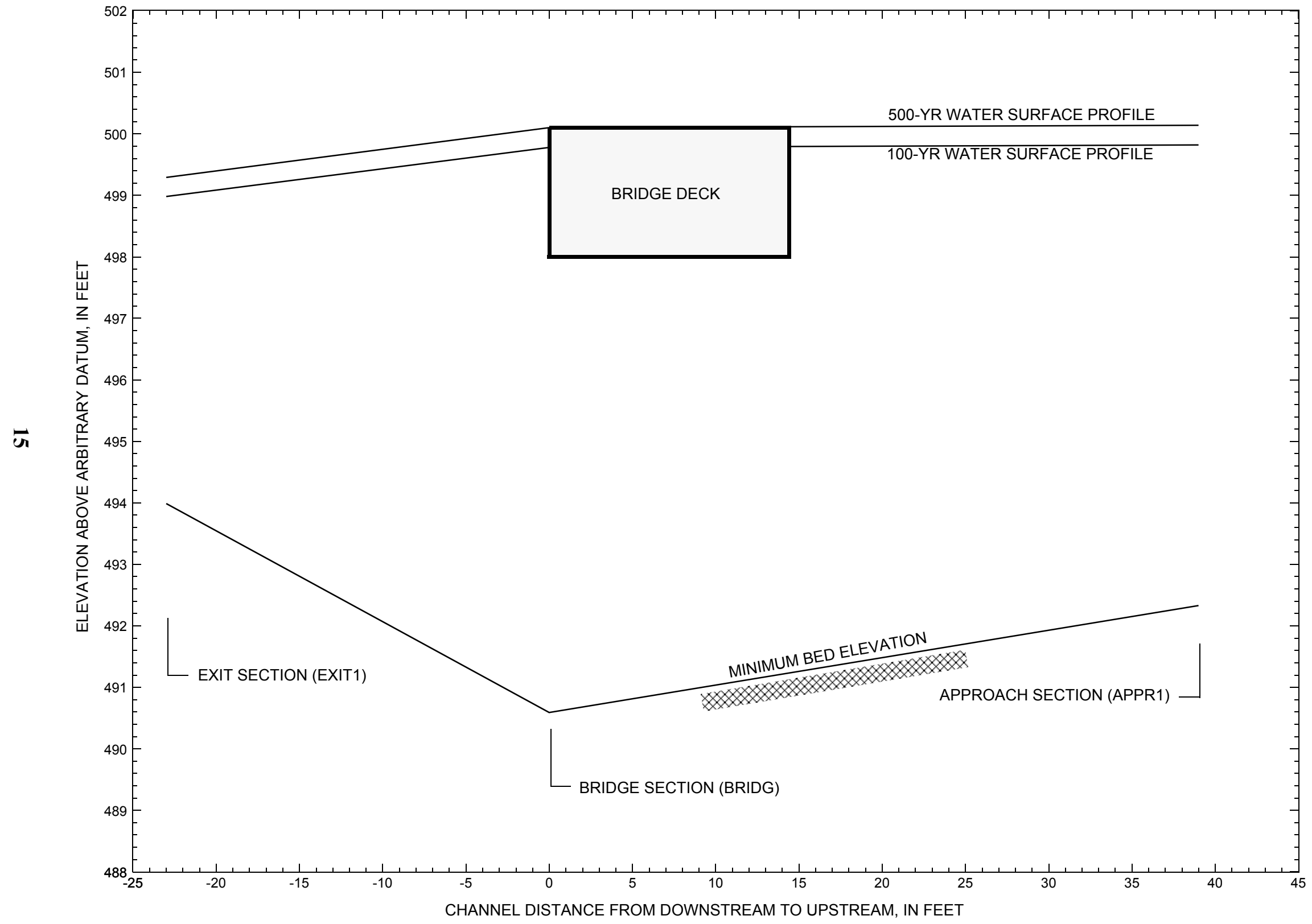

Figure 7. Water-surface profiles for the 100- and 500-yr discharges at structure LOWETH00080039 on Town Highway 8, crossing Potter Brook, Lowell, Vermont. 


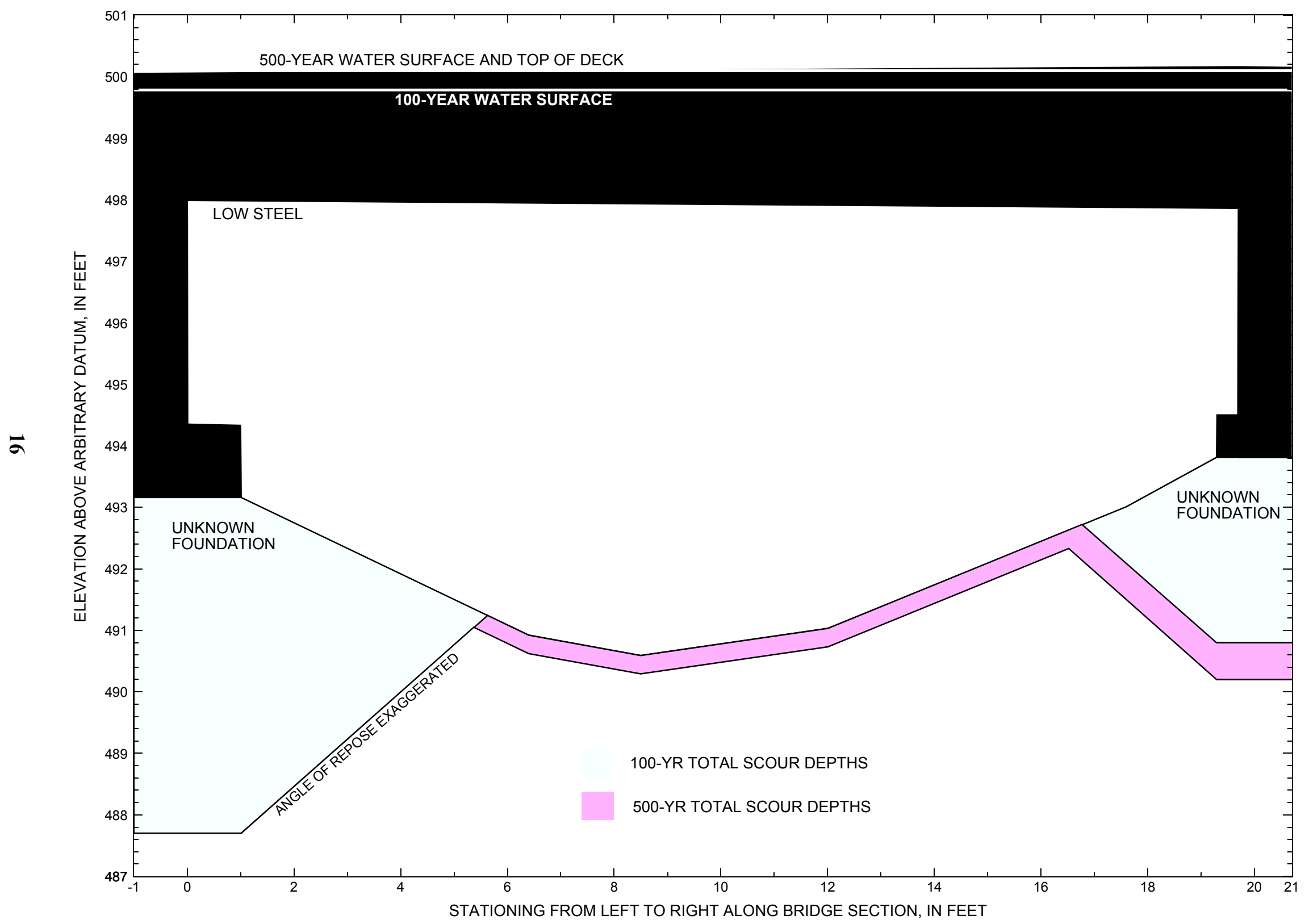

Figure 8. Scour elevations for the 100-yr and 500-yr discharges at structure LOWETH00080039 on Town Highway 8, crossing Potter Brook, Lowell, Vermont. 


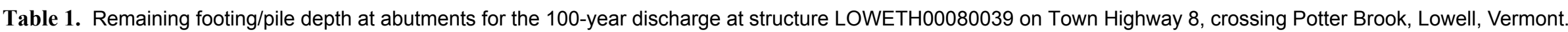
[VTAOT, Vermont Agency of Transportation; --,no data]

\begin{tabular}{|c|c|c|c|c|c|c|c|c|c|c|c|}
\hline Description & Station $^{1}$ & $\begin{array}{l}\text { VTAOT } \\
\text { minimum } \\
\text { low-chord } \\
\text { elevation } \\
\text { (feet) }\end{array}$ & $\begin{array}{l}\text { Surveyed } \\
\text { minimum } \\
\text { low-chord } \\
\text { elevation } \\
\text { (feet) }\end{array}$ & $\begin{array}{c}\text { Bottom of } \\
\text { footing } \\
\text { elevation } \\
\text { (feet) }\end{array}$ & $\begin{array}{c}\text { Channel } \\
\text { elevation at } \\
\text { abutment/ } \\
\text { pier }^{2} \\
\text { (feet) }\end{array}$ & $\begin{array}{l}\text { Contraction } \\
\text { scour depth } \\
\text { (feet) }\end{array}$ & $\begin{array}{l}\text { Abutment } \\
\text { scour } \\
\text { depth } \\
\text { (feet) }\end{array}$ & $\begin{array}{l}\text { Pier } \\
\text { scour } \\
\text { depth } \\
\text { (feet) }\end{array}$ & $\begin{array}{l}\text { Depth of } \\
\text { total scour } \\
\text { (feet) }\end{array}$ & $\begin{array}{c}\text { Elevation of } \\
\text { scour }^{2} \\
\text { (feet) }\end{array}$ & $\begin{array}{c}\text { Remaining } \\
\text { footing/pile } \\
\text { depth } \\
\text { (feet) }\end{array}$ \\
\hline \multicolumn{12}{|c|}{100 -yr. discharge is 1,070 cubic-feet per second } \\
\hline Left abutment & 0.0 & -- & 498.0 & -- & 493.2 & 0.0 & 5.5 & -- & 5.5 & 487.7 & -- \\
\hline Right abutment & 19.7 & -- & 497.9 & -- & 493.8 & 0.0 & 3.0 & -- & 3.0 & 490.8 & -- \\
\hline
\end{tabular}

1.Measured along the face of the most constricting side of the bridge.

2.Arbitrary datum for this study.

Table 2. Remaining footing/pile depth at abutments for the 500-year discharge at structure LOWETH00080039 on Town Highway 8, crossing Potter Brook, Lowell, Vermont. [VTAOT, Vermont Agency of Transportation; --, no data]

\begin{tabular}{|c|c|c|c|c|c|c|c|c|c|c|c|}
\hline Description & Station $^{1}$ & $\begin{array}{l}\text { VTAOT } \\
\text { minimum } \\
\text { low-chord } \\
\text { elevation } \\
\text { (feet) }\end{array}$ & $\begin{array}{l}\text { Surveyed } \\
\text { minimum } \\
\text { low-chord } \\
\text { elevation } \\
\text { (feet) }\end{array}$ & $\begin{array}{c}\text { Bottom of } \\
\text { footing } \\
\text { elevation } \\
\text { (feet) }\end{array}$ & $\begin{array}{c}\text { Channel } \\
\text { elevation at } \\
\text { abutment/ } \\
\text { pier }^{2} \\
\text { (feet) }\end{array}$ & $\begin{array}{l}\text { Contraction } \\
\text { scour depth } \\
\text { (feet) }\end{array}$ & $\begin{array}{l}\text { Abutment } \\
\text { scour } \\
\text { depth } \\
\text { (feet) }\end{array}$ & $\begin{array}{l}\text { Pier } \\
\text { scour } \\
\text { depth } \\
\text { (feet) }\end{array}$ & $\begin{array}{l}\text { Depth of } \\
\text { total scour } \\
\text { (feet) }\end{array}$ & $\begin{array}{c}\text { Elevation of } \\
\text { scour }^{2} \\
\text { (feet) }\end{array}$ & $\begin{array}{c}\text { Remaining } \\
\text { footing/pile } \\
\text { depth } \\
\text { (feet) }\end{array}$ \\
\hline \multicolumn{12}{|c|}{500 -yr. discharge is 1,500 cubic-feet per second } \\
\hline Left abutment & 0.0 & -- & 498.0 & -- & 493.2 & 0.3 & 2.2 & -- & 2.5 & 490.7 & -- \\
\hline Right abutment & 19.7 & -- & 497.9 & -- & 493.8 & 0.3 & 3.3 & -- & 3.6 & 490.2 & -- \\
\hline
\end{tabular}

1.Measured along the face of the most constricting side of the bridge.

2.Arbitrary datum for this study. 


\section{SELECTED REFERENCES}

Arcement, G.J., Jr., and Schneider, V.R., 1989, Guide for selecting Manning's roughness coefficients for natural channels and flood plains:

U.S. Geological Survey Water-Supply Paper 2339, 38 p.

Barnes, H.H., Jr., 1967, Roughness characteristics of natural channels: U.S. Geological Survey Water-Supply Paper 1849,213 p.

Benson, M. A., 1962, Factors Influencing the Occurrence of Floods in a Humid Region of Diverse Terrain: U.S. Geological Survey WaterSupply Paper 1580-B, 64 p.

Brown, S.A. and Clyde, E.S., 1989, Design of riprap revetment: Federal Highway Administration Hydraulic Engineering Circular No. 11, Publication FHWA-IP-89-016, 156 p.

Federal Highway Administration, 1983, Runoff estimates for small watersheds and development of sound design: Federal Highway Administration Report FHWA-RD-77-158.

Federal Highway Administration, 1993, Stream Stability and Scour at Highway Bridges: Participant Workbook: Federal Highway Administration Report FHWA-HI-91-011.

Froehlich, D.C., 1989, Local scour at bridge abutments in Ports, M.A., ed., Hydraulic Engineering--Proceedings of the 1989 National Conference on Hydraulic Engineering: New York, American Society of Civil Engineers, p. 13-18.

Hayes, D.C.,1993, Site selection and collection of bridge-scour data in Delaware, Maryland, and Virginia: U.S. Geological Survey WaterResources Investigation Report 93-4017, 23 p.

Johnson, C.G. and Tasker, G.D.,1974, Progress report on flood magnitude and frequency of Vermont streams: U.S. Geological Survey OpenFile Report 74-130, 37 p.

Lagasse, P.F., Schall, J.D., Johnson, F., Richardson, E.V., Chang, F., 1995, Stream Stability at Highway Structures: Federal Highway Administration Hydraulic Engineering Circular No. 20, Publication FHWA-IP-90-014, 144 p.

Laursen, E.M., 1960, Scour at bridge crossings: Journal of the Hydraulics Division, American Society of Civil Engineers, v. 86, no. HY2, p. 39-53.

Potter, W. D., 1957, Peak rates of runoff in the New England Hill and Lowland area, Bureau of Public Roads

Richardson, E.V. and Davis, S.R., 1995, Evaluating scour at bridges: Federal Highway Administration Hydraulic Engineering Circular No. 18, Publication FHWA-IP-90-017, 204 p.

Richardson, E.V., Simons, D.B., and Julien, P.Y., 1990, Highways in the river environment: Federal Highway Administration Publication FHWA-HI-90-016.

Ritter, D.F., 1984, Process Geomorphology: W.C. Brown Co., Debuque, Iowa, 603 p.

Shearman, J.O., 1990, User's manual for WSPRO--a computer model for water surface profile computations: Federal Highway Administration Publication FHWA-IP-89-027, 187 p.

Shearman, J.O., Kirby, W.H., Schneider, V.R., and Flippo, H.N., 1986, Bridge waterways analysis model; research report: Federal Highway Administration Publication FHWA-RD-86-108, 112 p.

Talbot, A.N., 1887, The determination of water-way for bridges and culverts.

U.S. Department of Transportation, 1993, Stream stability and scour at highway bridges, Participant Workbook: Federal Highway Administration Publication FHWA HI-91-011.

U.S. Geological Survey, 1986, Lowell, Vermont 7.5 Minute Series quadrangle map: U.S. Geological Survey Topographic Maps, Aerial photographs, 1981; Contour interval, 6 meters; Scale 1:24,000. 


\section{APPENDIX A: \\ WSPRO INPUT FILE}




\section{WSPRO INPUT FILE}

$\mathrm{XS}$

GR

GR

GR

GR

GR

$\mathrm{N}$

SA

*

XS

\section{*}

*

BR

GR

GR

GR

GR

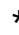

CD

$\mathrm{N}$

*

*

$\mathrm{XR}$

GR

GR

GR

*

AS

GR

GR

GR

GR

GR

GR

*

$\mathrm{N}$

SA
U.S. Geological Survey WSPRO Input File lowe039.wsp Hydraulic analysis for structure LOWETH00080039 Date: 08-MAY-97 Town Highway 8 crossing Potter Brook, Lowell, VT

EMB

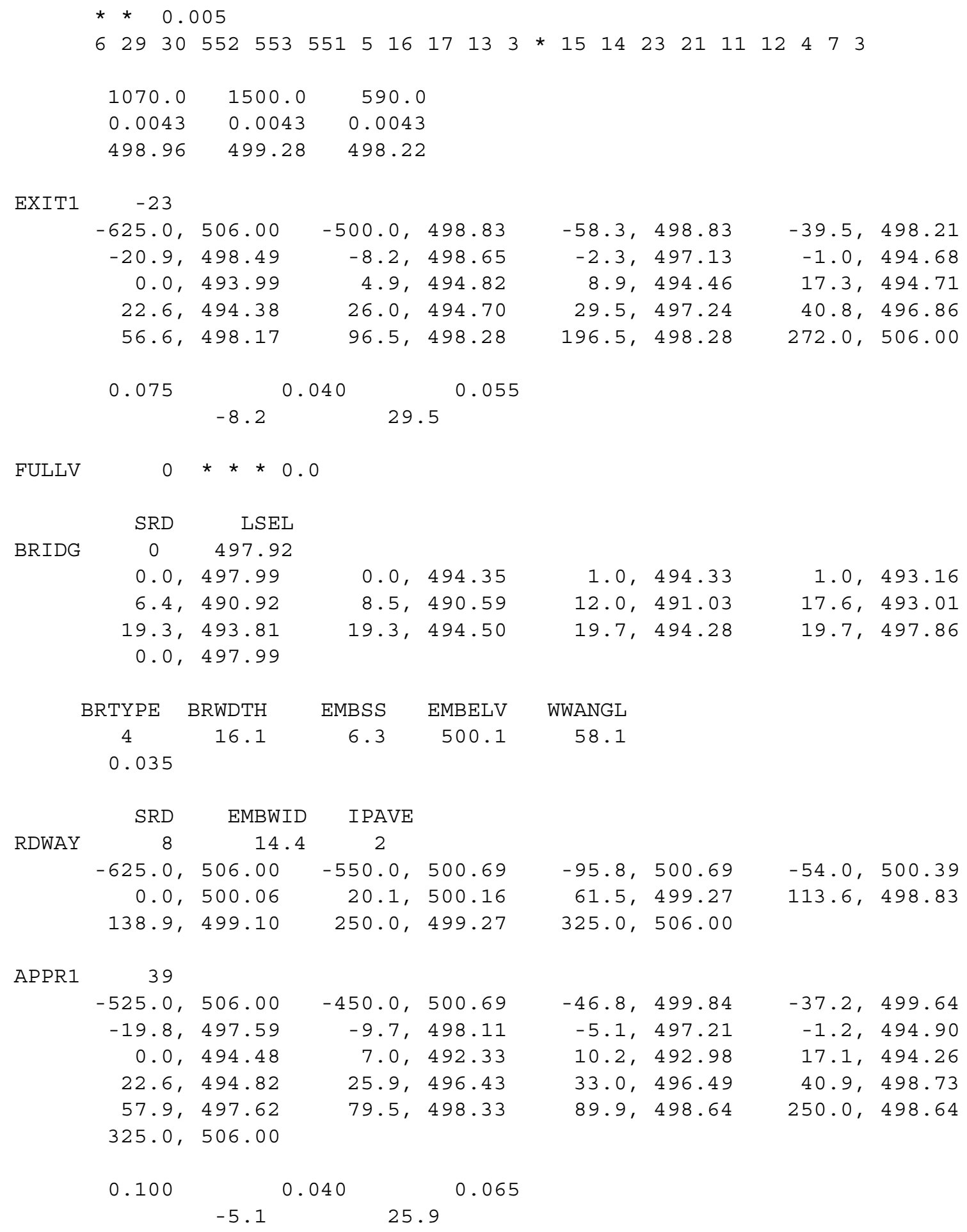


WSPRO INPUT FILE (continued)

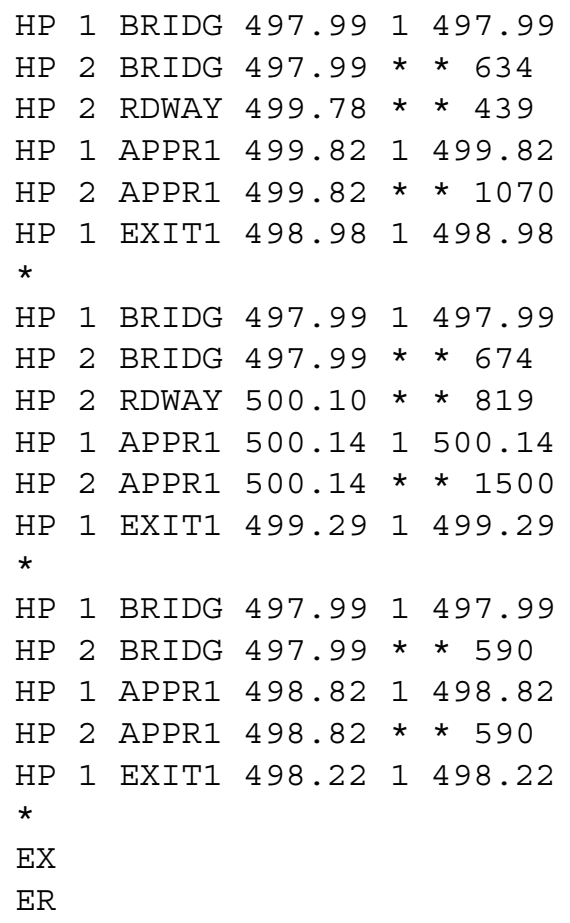

$\mathrm{ER}$ 


\section{APPENDIX B: \\ WSPRO OUTPUT FILE}


WSPRO OUTPUT FILE

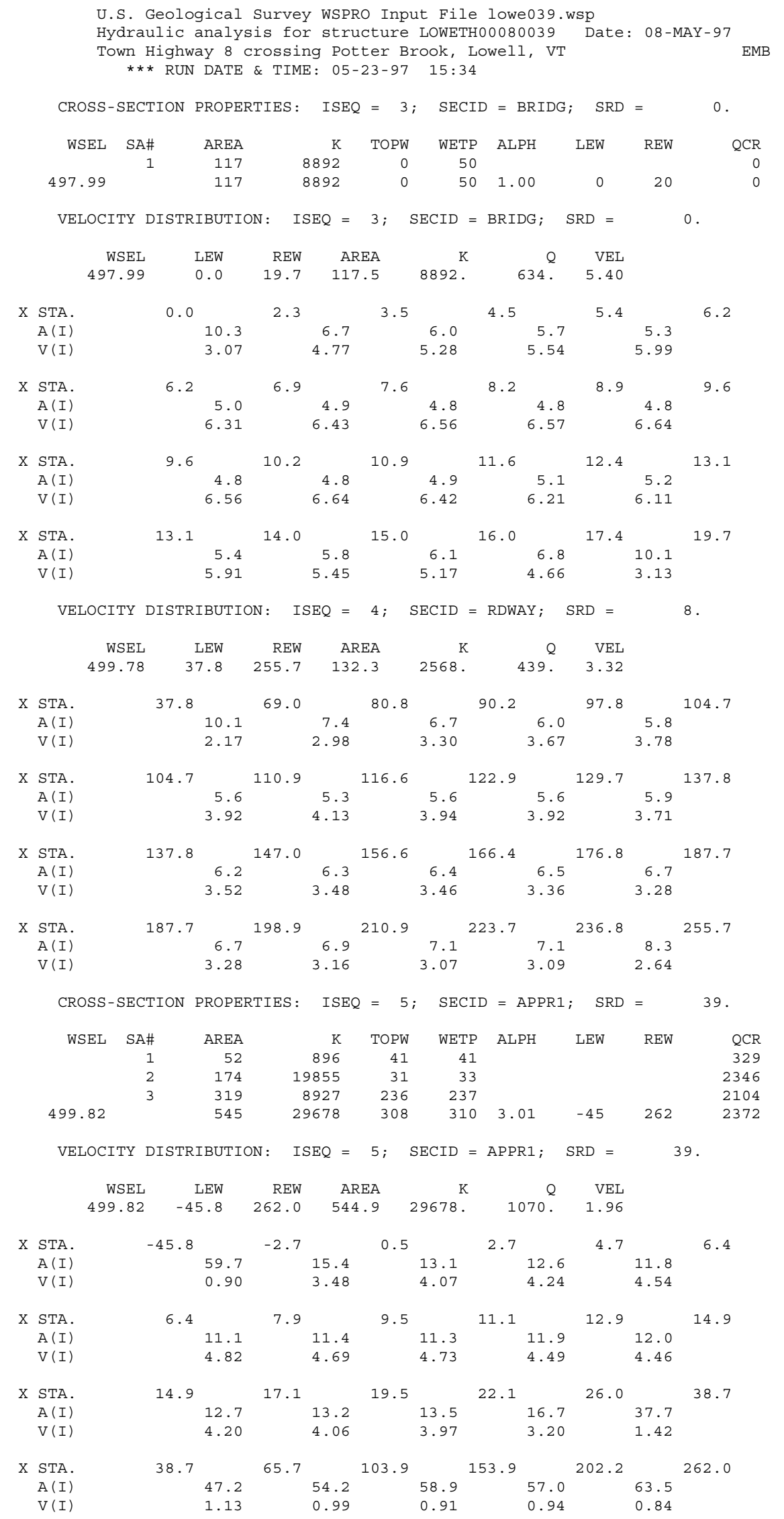


WSPRO OUTPUT FILE (continued)

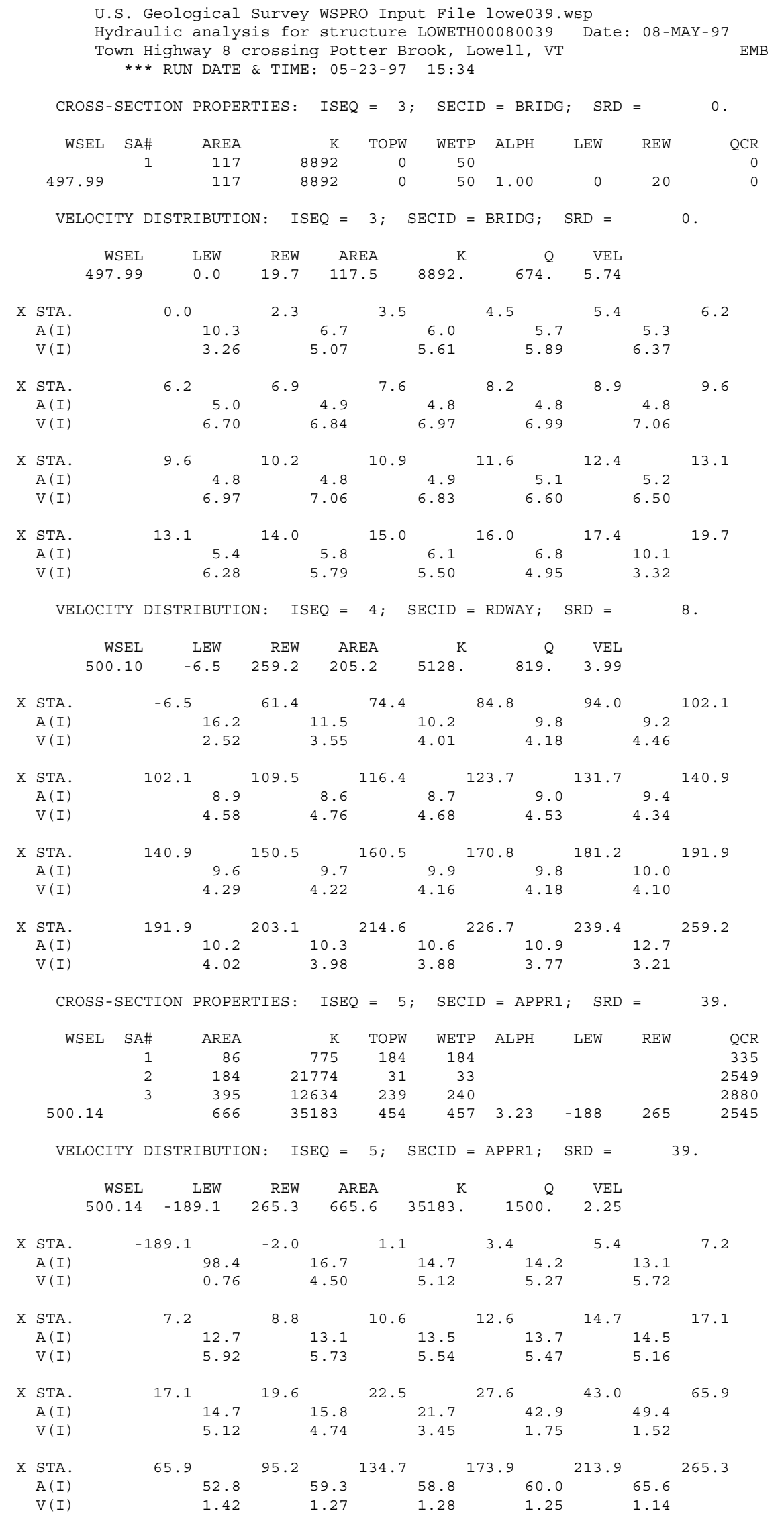


WSPRO OUTPUT FILE (continued)

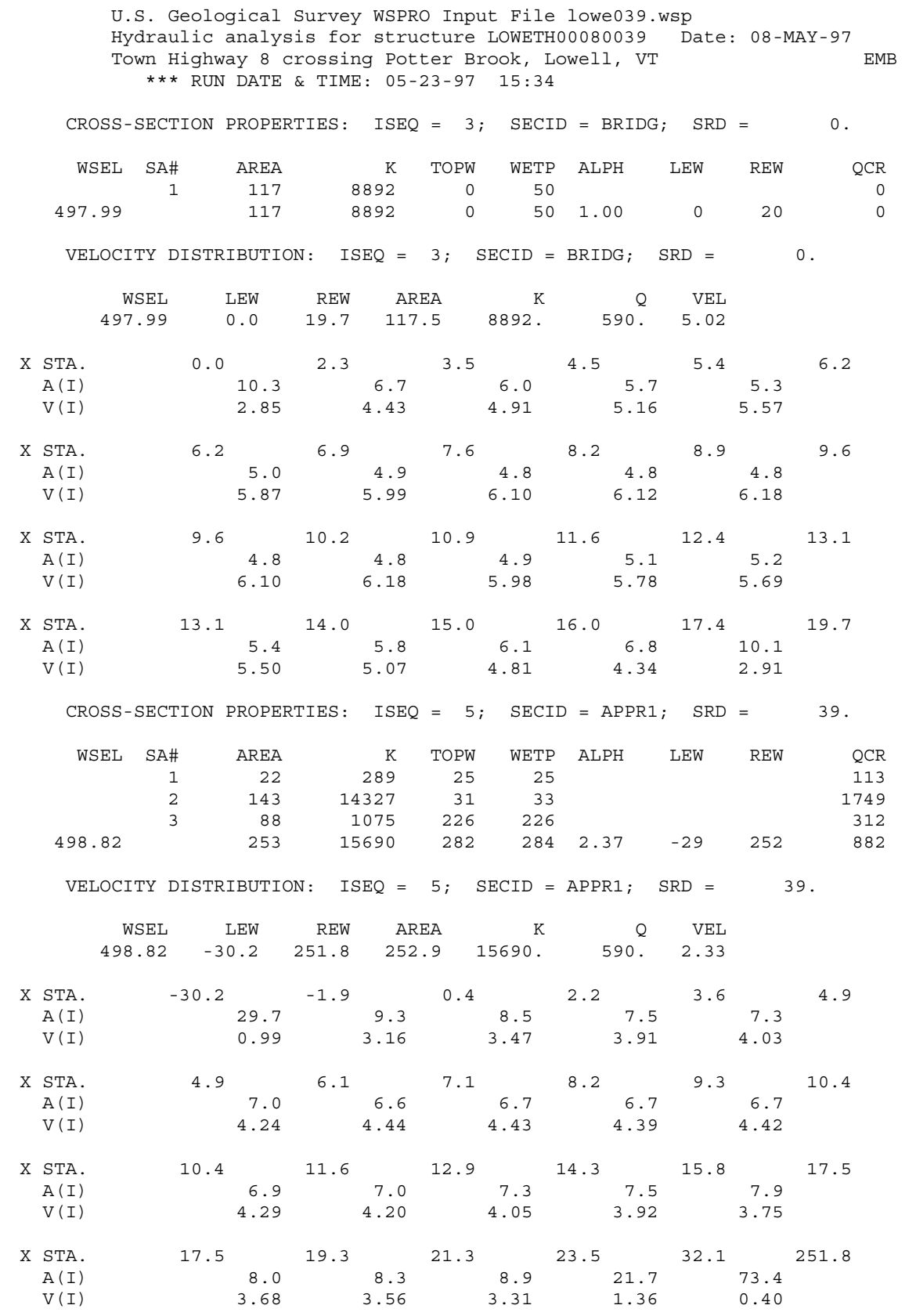


WSPRO OUTPUT FILE (continued)

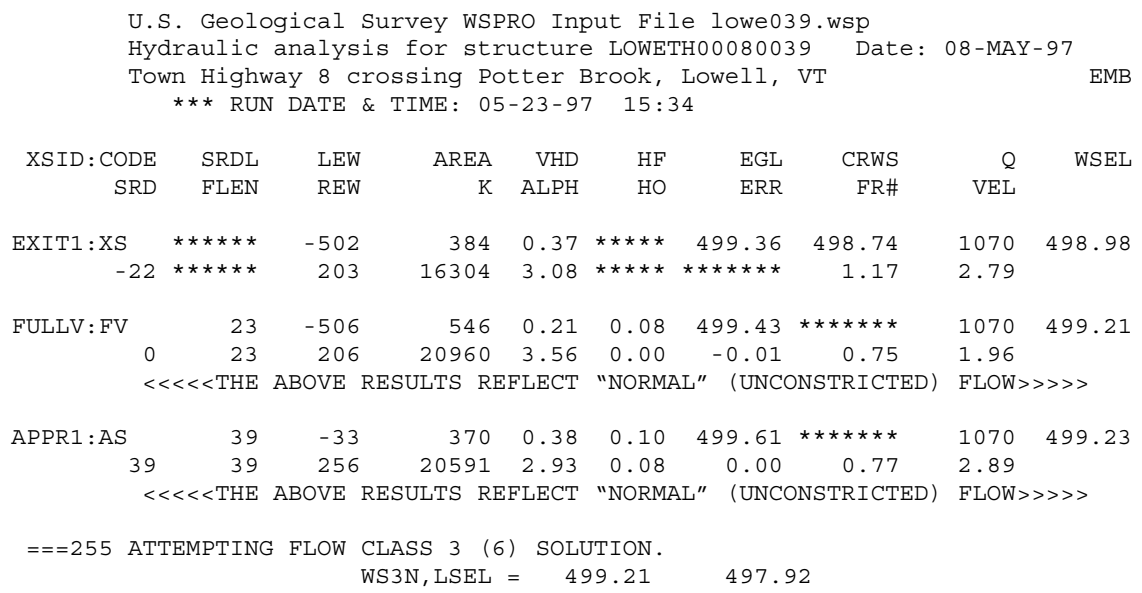

$<<<<$ RESULTS REFLECTING THE CONSTRICTED FLOW FOLLOW $>>>>>$

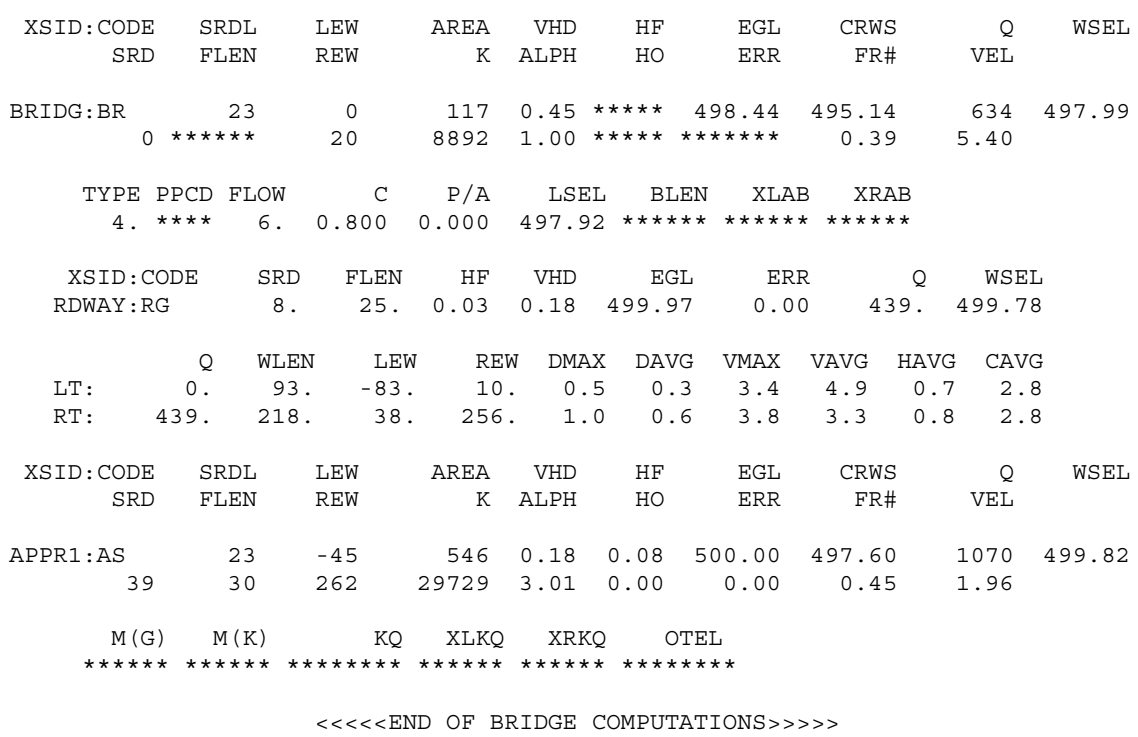

FIRST USER DEFINED TABLE.

\begin{tabular}{|c|c|c|c|c|c|c|c|c|}
\hline XSID : CODE & SRD & LEW & REW & Q & $\mathrm{K}$ & AREA & VEL & WSEL \\
\hline EXIT1:XS & -23 & -503. & 203. & 1070. & 16304 . & 384 . & 2.79 & 498.98 \\
\hline FULLV : FV & 0 & -507 & 206. & 1070. & 20960 . & 546. & 1.96 & 499.21 \\
\hline BRIDG : BR & 0 . & 0 & 20. & 634 & 8892 . & 117. & 5.40 & 497.99 \\
\hline RDWAY : RG & 8 & $\star * * * * *$ & 0. & 439. & 0 & $\star \star \star \star \star *$ & 2.00 & 499.78 \\
\hline APPR1:AS & 39. & -46 & 262 . & 1070. & 29729 . & 546. & 1.96 & 499.82 \\
\hline XSID: CODE & XLKQ & XRKQ & $\mathrm{r}$ & & & & & \\
\hline
\end{tabular}

SECOND USER DEFINED TABLE.

\begin{tabular}{|c|c|c|c|c|c|c|c|c|c|}
\hline XSID : COD & CRWS & FR\# & YMIN & YMAX & $\mathrm{HF}$ & $\mathrm{HO}$ & VHD & EGL & \\
\hline EXIT1:XS & 498.74 & 1.17 & 493.99 & 506. & $\star \star \star \star \star$ & *** & 0.37 & 199.36 & \\
\hline ULLV : FV & 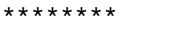 & .75 & 9 & 06.00 & 0.08 & 0.00 & 21 & 43 & 95 \\
\hline RI & 95.14 & 39 & & $497.99 *$ & $* * \star * \star *$ & $\star \star \star \star \star *$ & .45 & & \\
\hline & 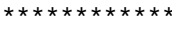 & 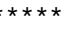 & & & $0.03 *$ & 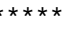 & 0.18 & & \\
\hline PPR1 : & 497.60 & 0.45 & 492.33 & 506.00 & 0.08 & 0.00 & 0.18 & 500.00 & 499 \\
\hline
\end{tabular}


WSPRO OUTPUT FILE (continued)

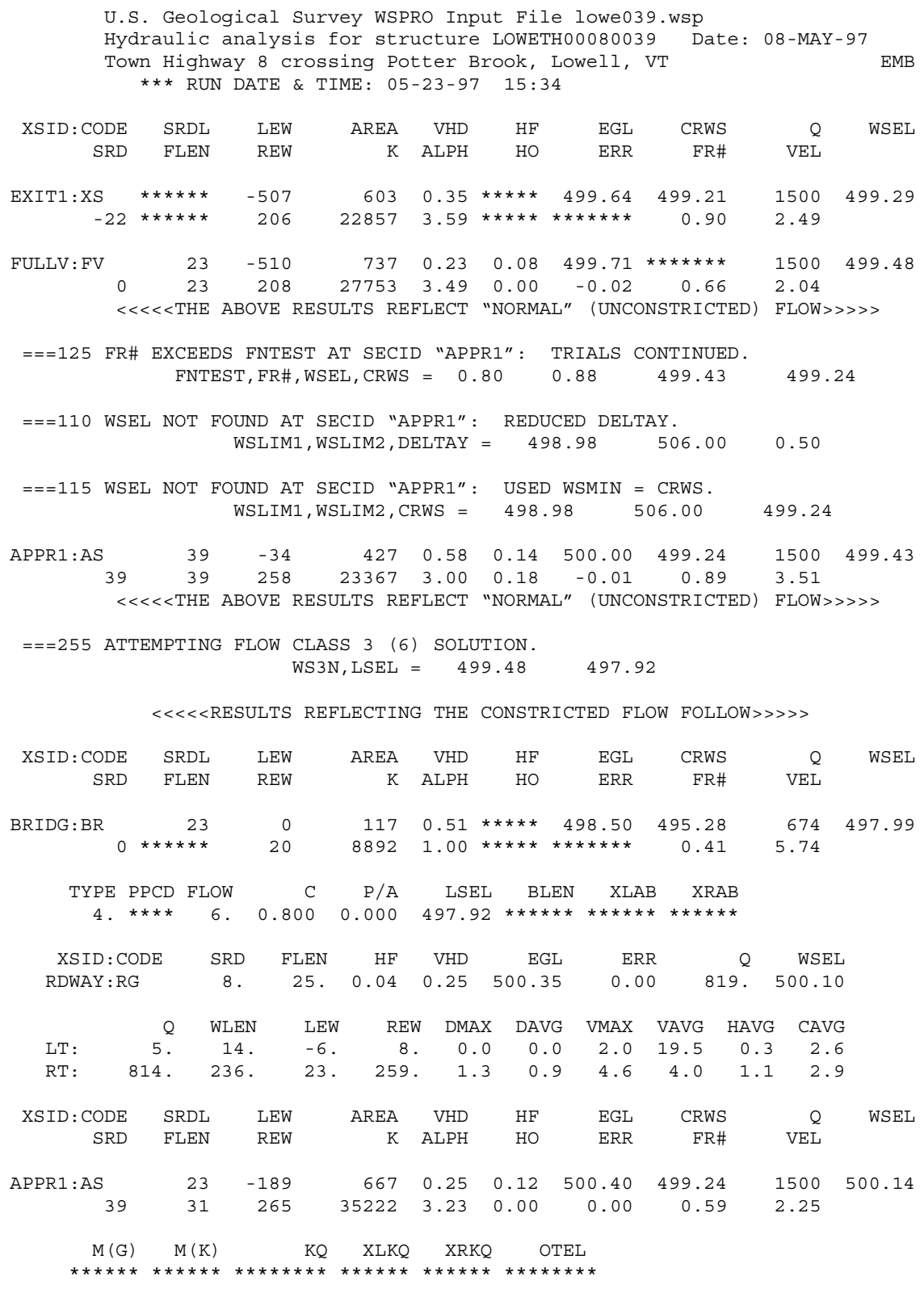

$<<<<<$ END OF BRIDGE COMPUTATIONS $>>>>>$

FIRST USER DEFINED TABLE.

\begin{tabular}{|c|c|c|c|c|c|c|c|c|}
\hline XSID : CODE & SRD & LEW & REW & $\mathrm{Q}$ & $\mathrm{K}$ & AREA & VEL & WSEL \\
\hline EXIT1:XS & -23. & -508. & 206. & 1500. & 22857 . & 603. & 2.49 & 499.29 \\
\hline FULLV : FV & 0 & -511. & 208. & 1500. & 27753 . & 737. & 2.04 & 499.48 \\
\hline BRIDG : BR & 0 . & 0. & 20. & 674 & 8892 . & 117. & 5.74 & 497.99 \\
\hline RDWAY : RG & 8. & $\star * \star * *$ & 5. & 819. & 0 & $\star * * * *$ & 2.00 & 500.1 \\
\hline APPR I : AS & 39. & -190. & 265. & 1500. & 35222 . & 667. & 2.25 & 500.1 \\
\hline
\end{tabular}

XSID:CODE XLKQ XRKQ KQ

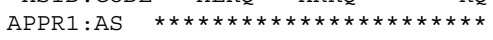

SECOND USER DEFINED TABLE.

\begin{tabular}{|c|c|c|c|c|c|c|c|c|c|}
\hline XSID : CODE & CRWS & FR\# & YMIN & YMAX & $\mathrm{HF}$ & $\mathrm{HO}$ & VHD & EGL & WSEI \\
\hline EXIT1:XS & 499.21 & 0.90 & 493.99 & 506.00 * & 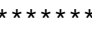 & $\star \star \star \star \star *$ & 0.35 & 499.64 & 499.2 \\
\hline FULLV : FV & $\star * \star * \star * \star * *$ & 0.66 & 493.99 & 506.00 & 0.08 & 0.00 & 0.23 & 499.71 & 499 \\
\hline BRIDG : BR & 495.28 & 0.41 & 490.59 & $497.99 *$ & $\star \star \star \star \star \star \star * *$ & $\star \star \star \star \star *$ & 0.51 & 498.50 & 497 \\
\hline RDWAY : RG & 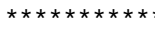 & $\star * \star * *$ & 498.83 & 506.00 & $0.04 * *$ & $\star \star \star \star \star *$ & 0.25 & 500.35 & 500.1 \\
\hline APPR 1 : AS & 499.24 & 0.59 & 492.33 & 506.00 & 0.12 & 0.00 & 0.25 & 500.40 & 500. \\
\hline
\end{tabular}


WSPRO OUTPUT FILE (continued)

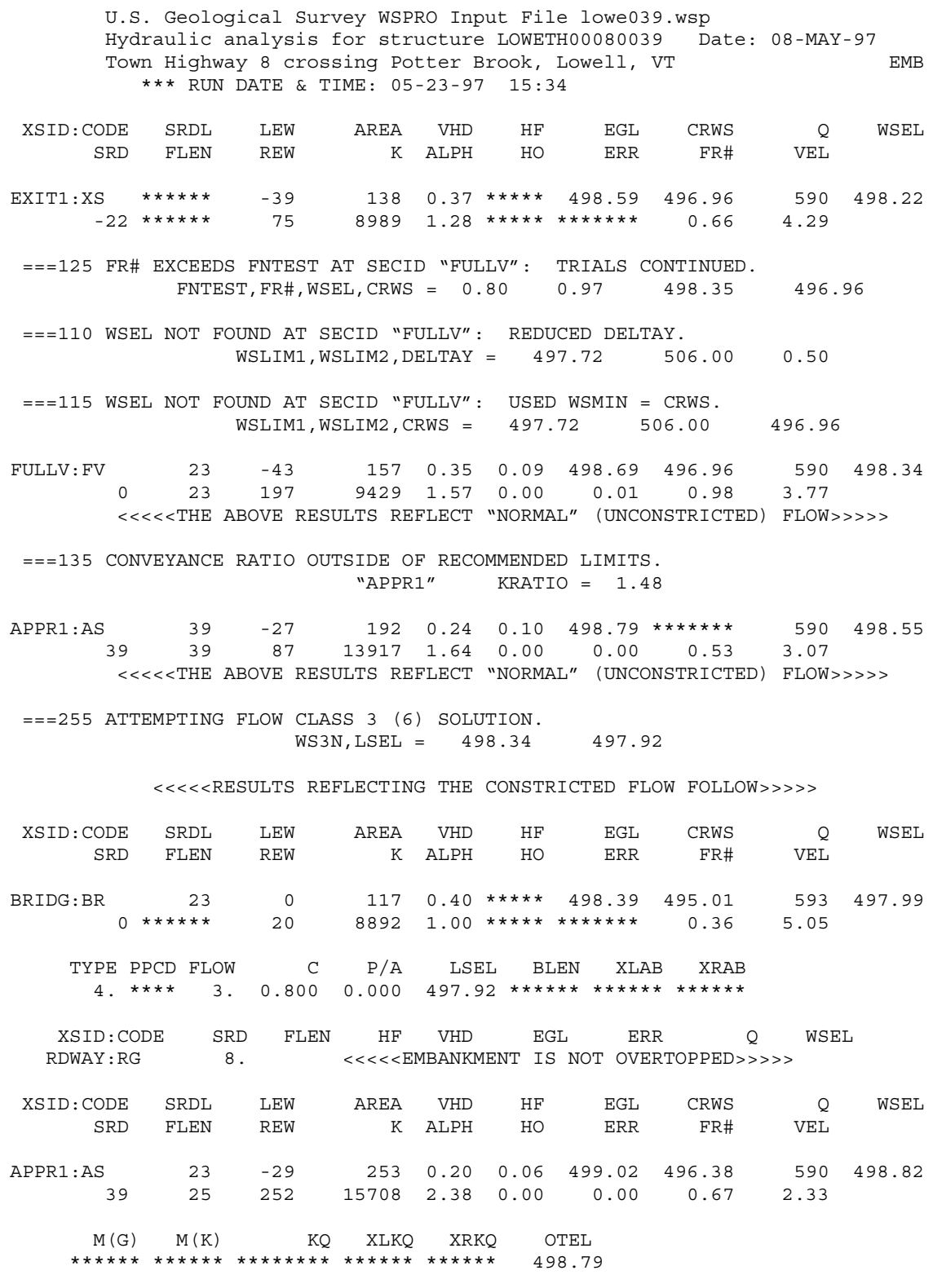

$<<<<$ END OF BRIDGE COMPUTATIONS $>>>>>$

FIRST USER DEFINED TABLE.

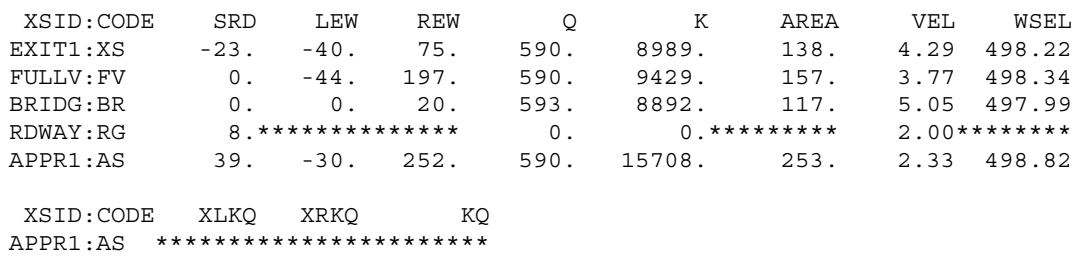

SECOND USER DEFINED TABLE.

$\begin{array}{lcrrrrrrrr}\text { XSID:CODE } & \text { CRWS } & \text { FR\# } & \text { YMIN } & \text { YMAX } & \text { HF } & \text { HO } & \text { VHD } & \text { EGL } & \text { WSEL } \\ \text { EXIT1:XS } & 496.96 & 0.66 & 493.99 & 506.00 * * * * * * * * * * * & 0.37 & 498.59 & 498.22 \\ \text { FULLV:FV } & 496.96 & 0.98 & 493.99 & 506.00 & 0.09 & 0.00 & 0.35 & 498.69 & 498.34 \\ \text { BRIDG:BR } & 495.01 & 0.36 & 490.59 & 497.99 * * * * * * * * * * * & 0.40 & 498.39 & 497.99 \\ \text { RDWAY:RG } & * * * * * * * * * * * * * * & 498.83 & 506.00 * * * * * * * * * * * & 0.11 & 499.39 * * * * * * \\ \text { APPRI:AS } & 496.38 & 0.67 & 492.33 & 506.00 & 0.06 & 0.00 & 0.20 & 499.02 & 498.82 \\ \text { ER } & & & & & & & & & \end{array}$




\section{APPENDIX C:}

\section{BED-MATERIAL PARTICLE-SIZE DISTRIBUTION}




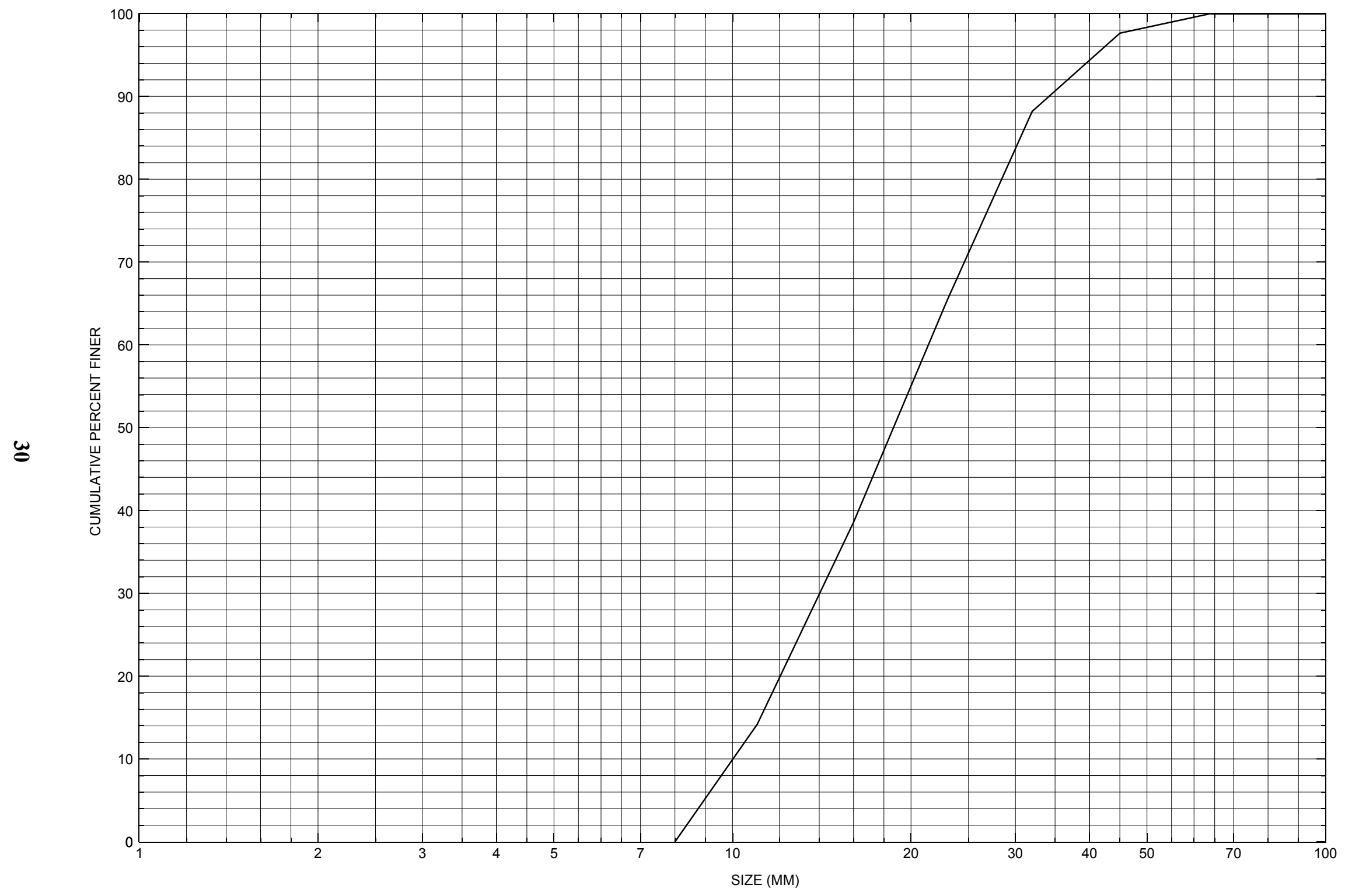

Appendix C. Bed material particle-size distribution for a pebble count in the channel approach of structure LOWETH00080039, in Lowell, Vermont. 


\section{APPENDIX D: \\ HISTORICAL DATA FORM}




\section{Structure Number LOWETH00080039}

\section{General Location Descriptive}

Data collected by (First Initial, Full last name) $\underline{\text { L }}$. MEDALIE

Date $(M M / D D / Y Y) \_\mathbf{0 3} / \underline{\mathbf{0 7}} / \underline{95}$

Highway District Number (I - 2; nn) $\mathbf{0 9}$

Town (FIPS place code; I - 4; nnnnn) $\mathbf{4 0 5 2 5}$

Waterway ( $($ - 6) POTTER BROOK

Route Number $\underline{\text { TH } 8}$

Topographic Map Lowell

Latitude (I - 16; nnnn.n) $\mathbf{4 4 4 7 4}$
County (FIPS county code; I - 3; nnn)

Mile marker (I - 11; nnn.nnn) $\underline{\mathbf{0 0 0 0 0 0}}$

Road Name (I - 7): -

Vicinity (I - 9) 0.1 MI TO JCT W CL2 TH3

Hydrologic Unit Code: $\underline{\mathbf{0 2 0 1 0 0 0 7}}$

Longitude (i - 17; nnnnn.n) $\mathbf{7 2 2 9 6}$

\section{Select Federal Inventory Codes}

FHWA Structure Number (I - 8) 10101300391013

Maintenance responsibility $(I-21 ; n n) \quad \mathbf{0 3}$

Year built (I - 27; YYYY) 1958

Average daily traffic, ADT (I - 29; nnnnnn) $\underline{000010}$

Year of ADT (I - 30; YY) $\mathbf{9 4}$

Opening skew to Roadway $(I-34 ; n n) \quad \mathbf{0 0}$

Operational status $(I-41 ; X) \quad \mathbf{A}$

Structure type (I- 43; nnn) $\mathbf{3 0 2}$

Approach span structure type $(I-44 ; n n n)$ 000

Number of spans (I - 45; nnn) $\underline{\mathbf{0 0 1}}$

Number of approach spans (I - 46; nnnn) $\mathbf{0 0 0 0}$

Comments:

The structural inspection report of 6/1/93 indicates the structure is a steel stringer type bridge with a timber deck. Both abutment walls have only minor concrete spalling reported. The left abutment footing is exposed such that the adjacent streambed level is up to 1.5 feet below the top of the footing, with no apparent undermining. The waterway takes a moderate to sharp turn just upstream. Some minor bank erosion is reported upstream from the end of the left abutment. There is a shallow, silty sand point bar in front of right abutment. The wingwalls are noted as leaning forward slightly. There is no stone fill protection reported at this site. The streambed material consists of mostly silt and clay with some sand. 


\section{Bridge Hydrologic Data}

Is there hydrologic data available? $\mathbf{N}$ if No, type ctrl- $n$ VTAOT Drainage area $\left(\mathrm{mi}^{2}\right)^{2}$ : -

Terrain character:

Stream character \& type:

Streambed material: Mainly silt and clay with some sand

Discharge Data (cfs): $\quad \mathrm{Q}_{2.33}$

$$
\mathrm{Q}_{50}-
$$

$\mathrm{Q}_{10}-$

$$
\begin{aligned}
& Q_{25} \ldots \\
& Q_{500}-
\end{aligned}
$$

Record flood date (MM /DD/YY): - $/$ - $/$ Water surface elevation $(f t):-$

Estimated Discharge (cfs): Velocity at $\mathrm{Q}-$ $(\mathrm{ft} / \mathrm{s}):$

Ice conditions (Heavy, Moderate, Light) : Debris (Heavy, Moderate, Light):

The stage increases to maximum highwater elevation (Rapidly, Not rapidly):

The stream response is (Flashy, Not flashy):

Describe any significant site conditions upstream or downstream that may influence the stream's stage: -

Watershed storage area (in percent): - _ \%

The watershed storage area is: - (1-mainly at the headwaters; 2- uniformly distributed; 3-immediatly upstream oi the site)

Water Surface Elevation Estimates for Existing Structure:

\begin{tabular}{|l|l|l|l|l|l|}
\hline Peak discharge frequency & $Q_{2.33}$ & $Q_{10}$ & $Q_{25}$ & $Q_{50}$ & $Q_{100}$ \\
Water surface elevation (ft)) & - & - & - & - & - \\
Velocity (ft/sec) & - & - & - & - & - \\
\hline
\end{tabular}

Long term stream bed changes: -

Is the roadway overtopped below the $Q_{100}$ ? (Yes, No, Unknown): Frequency: -

Relief Elevation (ft):

Discharge over roadway at $Q_{100}\left(f^{3} / \mathrm{sec}\right)$ :

Are there other structures nearby? (Yes, No, Unknown): Upstream distance (miles): Town: If No or Unknown, type ctrl-n os Highway No. :Structure No. : Year Built:

Clear span (ft): Clear Height $(f t)$ : Full Waterway $\left(f^{2}\right)$ : 
Downstream distance (miles): Town: Year Built:

Highway No. : Structure No. : Structure Type:

Clear span (ft): Clear Height $(f t)$ : Full Waterway $\left(f^{2}\right)$ : -

Comments:

\section{USGS Watershed Data}

Watershed Hydrographic Data

Drainage area (DA)

4.69 $\mathrm{mi}^{2}$

Lake/pond/swamp area

0.06 $\mathrm{mi}^{2}$

Watershed storage (ST) $\%$

Bridge site elevation 1190 $\mathrm{ft}$

Headwater elevation 3196 $\mathrm{ft}$

Main channel length

3.96 $\mathrm{mi}$

$10 \%$ channel length elevation $\mathbf{1 2 0 2}$ $\mathrm{ft} \quad 85 \%$ channel length elevation $\mathrm{ft}$

Main channel slope $(S)$

(S) 397.64 $\mathrm{ft} / \mathrm{mi}$

Watershed Precipitation Data

Average site precipitation in

Average headwater precipitation in

Maximum 2yr-24hr precipitation event $(124,2)$ in

Average seasonal snowfall (Sn) $\mathrm{ft}$ 


\section{Bridge Plan Data}

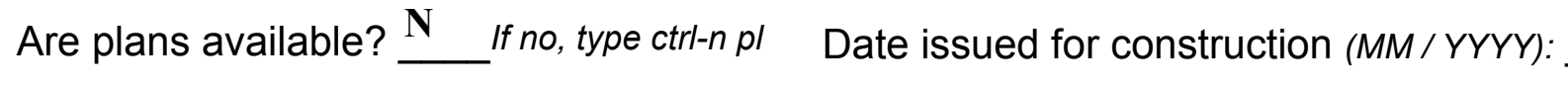

Project Number

Minimum channel bed elevation:

Low superstructure elevation: USLAB DSLAB USRAB DSRAB Benchmark location description:

NO BENCHMARK INFORMATION

Reference Point (MSL, Arbitrary, Other): Datum (NAD27, NAD83, Other):

Foundation Type: 4

If 1: Footing Thickness

If 2: Pile Type: (1-Wood; 2-Steel or metal; 3-Concrete)

If 3 : Footing bottom elevation:

Is boring information available? $\mathbf{N}$ If no, type ctrl-n bi Number of borings taken:

Foundation Material Type: $\mathbf{3}$ (1-regolith, 2-bedrock, 3-unknown)

Briefly describe material at foundation bottom elevation or around piles:

NO FOUNDATION MATERIAL INFORMATION

Comments:

NO PLANS. 


\section{Cross-sectional Data}

Is cross-sectional data available? $\mathbf{N}$ If no, type ctrl-n xs

Source (FEMA, VTAOT, Other)? -

Comments:

\section{NO CROSS SECTION INFORMATION}

\begin{tabular}{|l|l|l|l|l|l|l|l|l|l|l|l|}
\hline Station & - & - & - & - & - & - & - & - & - & - & - \\
\hline Feature & - & - & - & - & - & - & - & - & - & - & - \\
\hline $\begin{array}{l}\text { Low cord } \\
\text { elevation }\end{array}$ & - & - & - & - & - & - & - & - & - & - & - \\
\hline $\begin{array}{l}\text { Bed } \\
\text { elevation }\end{array}$ & - & - & - & - & - & - & - & - & - & - & - \\
\hline $\begin{array}{l}\text { Low cord to } \\
\text { bed length }\end{array}$ & - & - & - & - & - & - & - & - & - & - & - \\
\hline Station & - & - & - & - & - & - & - & - & - & - & - \\
\hline Feature & - & - & - & - & - & - & - & - & - & - & - \\
\hline $\begin{array}{l}\text { Low cord } \\
\text { elevation }\end{array}$ & - & - & - & - & - & - & - & - & - & - & - \\
\hline $\begin{array}{l}\text { Bed } \\
\text { elevation }\end{array}$ & - & - & - & - & - & - & - & - & - & - & - \\
\hline $\begin{array}{l}\text { Low cord to } \\
\text { bed length }\end{array}$ & - & - & - & - & - & - & - & - & - & - & - \\
\hline
\end{tabular}

Source (FEMA, VTAOT, Other)? NO

Comments: CROSS SECTION INFORMATION

\begin{tabular}{|l|l|l|l|l|l|l|l|l|l|l|l|}
\hline Station & - & - & - & - & - & - & - & - & - & - & - \\
\hline Feature & - & - & - & - & - & - & - & - & - & - & - \\
\hline $\begin{array}{l}\text { Low cord } \\
\text { elevation }\end{array}$ & - & - & - & - & - & - & - & - & - & - & - \\
\hline $\begin{array}{l}\text { Bed } \\
\text { elevation }\end{array}$ & - & - & - & - & - & - & - & - & - & - & - \\
\hline $\begin{array}{l}\text { Low cord to } \\
\text { bed length }\end{array}$ & - & - & - & - & - & - & - & - & - & - & - \\
\hline Station & - & - & - & - & - & - & - & - & - & - & - \\
\hline Feature & - & - & - & - & - & - & - & - & - & - & - \\
\hline $\begin{array}{l}\text { Low cord } \\
\text { elevation }\end{array}$ & - & - & - & - & - & - & - & - & - & - & - \\
\hline $\begin{array}{l}\text { Bed } \\
\text { elevation }\end{array}$ & - & - & - & - & - & - & - & - & - & - & - \\
\hline $\begin{array}{l}\text { Low cord to } \\
\text { bed length }\end{array}$ & - & - & - & - & - & - & - & - & - & - & - \\
\hline
\end{tabular}




\section{APPENDIX E: \\ LEVEL I DATA FORM}


U. S. Geological Survey

Bridge Field Data Collection and Processing Form

Qa/Qc Check by: RB Date: $4 / 9 / 96$

\section{Structure Number}

LOWETH00080039

Computerized by: $\underline{\mathbf{R B}}$ Date: $4 / 12 / 96$

Reviewd by:

EMB Date: $\underline{5 / 27 / 97}$

\section{A. General Location Descriptive}

1. Data collected by (First Initial, Full last name) $\mathbf{J}$. DEGNAN

Date $(M M / D D / Y Y)$ $15 / 1995$

2. Highway District Number 09

Mile marker 000

County ORLEANS (019)

Town LOWELL (40525)

Waterway $(I$ - 6) POTTER BROOK

Road Name -

Route Number TH 8

Hydrologic Unit Code: $\mathbf{0 2 0 1 0 0 0 7}$

3. Descriptive comments:

This site is located 0.1 mile from the intersection of TH 8 with TH 3.

\section{B. Bridge Deck Observations}
4. Surface cover... LBUS 6
RBUS 5
LBDS 5
RBDS 5
Overall 5

(2b us, ds,lb,rb: 1- Urban; 2- Suburban; 3- Row crops; 4- Pasture; 5- Shrub- and brushland; 6- Forest; 7- Wetland)
5. Ambient water surface... US 1
UB 1
DS 1
(1- pool; 2- riffle)

6. Bridge structure type 1 (1- single span; 2- multiple span; 3- single arch; 4- multiple arch; 5-cylindrical culvert; 6- box culvert; or 7- other)
7. Bridge length 23
(feet)
Span length $\mathbf{2 1}$
(feet)
Bridge width 14.4 (feet)

\section{Road approach to bridge:}
8. LB 0
RB 1
( 0 even, 1- lower, 2- higher)
9. LB_2
RB $\underline{2}$
(1-Paved, 2- Not paved)

10. Embankment slope (run / rise in feet / foot)

$$
\text { US left }
$$

8.1:1

US right

4.5:1

\begin{tabular}{|c|c|c|c|c|}
\hline & \multicolumn{2}{|c|}{ Protection } & \multirow{2}{*}{ 13.Erosion } & \multirow{2}{*}{ 14.Severity } \\
\hline & 11.Type & 12.Cond. & & \\
\hline LBUS & 0 & - & 2 & 1 \\
\hline RBUS & 2 & 1 & 2 & 1 \\
\hline RBDS & $\mathbf{0}$ & - & $\mathbf{0}$ & - \\
\hline LBDS & $\mathbf{0}$ & - & 0 & - \\
\hline
\end{tabular}

Bank protection types: 0- none; 1- $<12$ inches;

2- < 36 inches; 3- < 48 inches;

4- < 60 inches; 5- wall / artificial levee

Bank protection conditions: 1- good; 2- slumped;

3- eroded; 4- failed

Erosion: 0 - none; 1- channel erosion; 2 -

road wash; 3- both; 4- other

Erosion Severity: 0 - none; 1- slight; 2- moderate; 3- severe

\section{Channel approach to bridge (BF):}

15. Angle of approach: $\mathbf{2 5}$

16. Bridge skew: $\mathbf{2 0}$

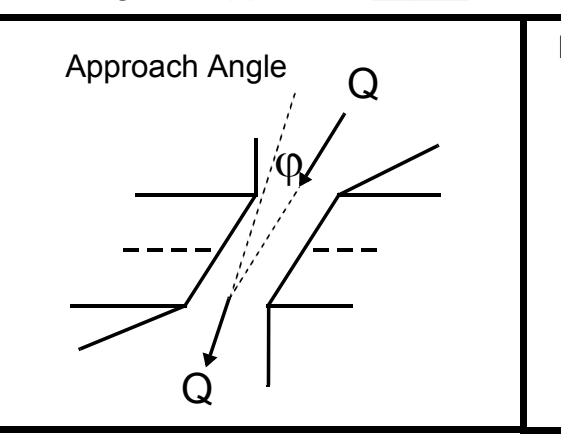

17. Channel impact zone 1 :

Where? LB (LB, RB)

Range? 30 feet US

Channel impact zone 2:

Where? $(L B, R B)$

Range? - $\quad$ feet (US, UB, DS) to feet -

Impact Severity: 0- none to very slight; 1- Slight; 2- Moderate; 3- Severe 
18. Bridge Type: 4

1a- Vertical abutments with wingwalls

$1 \mathrm{~b}$ - Vertical abutments without wingwalls

2- Vertical abutments and wingwalls, sloping embankment Wingwalls perpendicular to abut. face

3- Spill through abutments

4- Sloping embankment, vertical wingwalls and abutments

Wingwall angle less than $90^{\circ}$.

19. Bridge Deck Comments (surface cover variations, measured bridge and span lengths, bridge type variations, approach overflow width, etc.)

The impact zone on the upstream left bank is complicated by a small confluence.

The road approach protection on the upstream right bank consists of only 2 boulders.

The bridge dimensions measured in the field were the same as the historical values shown on the previous page.

\section{Upstream Channel Assessment}

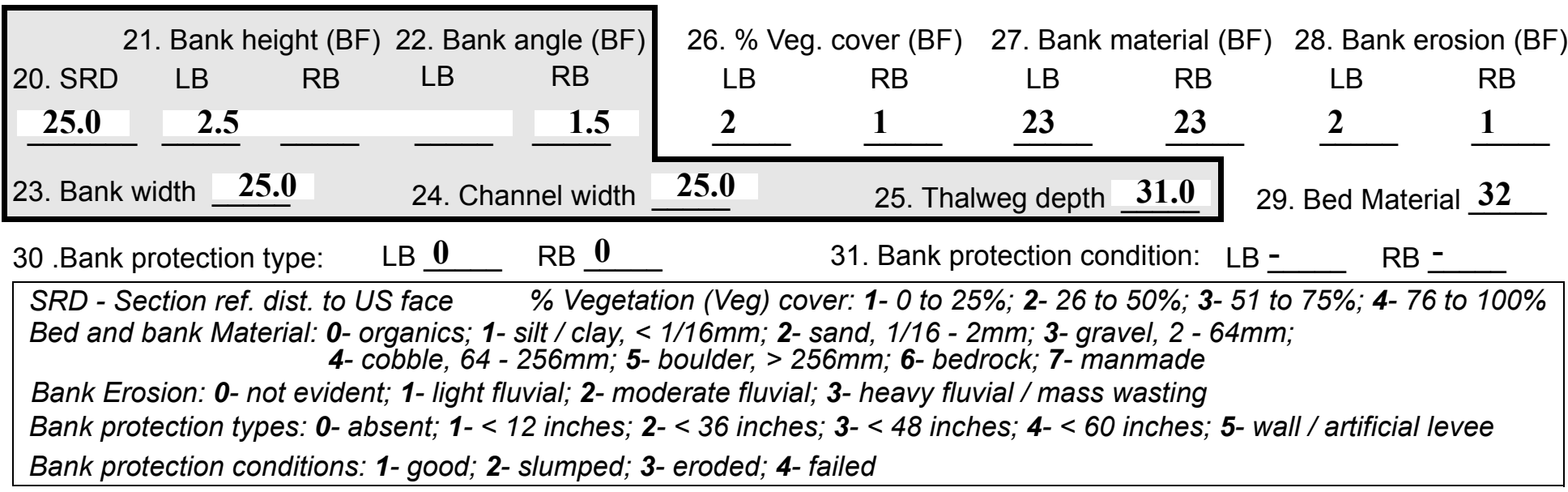

32. Comments (bank material variation, minor inflows, protection extent, etc.):

The bank protection on the left bank may be material left after the erosion of the top soil.

There is a minor inflow on the left bank. Since the bridge and the roadway constrict flow through the bordering low lands, there are many dry channels on both banks spilling into the main channel just before the bridge. 
33.Point/Side bar present? $\mathbf{N}(Y$ or $N$. if $N$ type ctrl-n pb)34. Mid-bar distance: -

35. Mid-bar width: -

36. Point bar extent: feet (US, UB) to feet (US, UB, DS) positioned $\%$ LB to $\% \mathrm{RB}$

37. Material: -

38. Point or side bar comments (Circle Point or Side; Note additional bars, material variation, status, etc.):

NO POINT BARS

39. Is a cut-bank present? $\underline{\mathbf{Y}}(\mathrm{Y}$ or if $N$ type $c t r-n c b)$

40. Where? $\underline{\mathbf{L B}}$ (LB or RB)

41. Mid-bank distance: $\mathbf{1 5}$

42. Cut bank extent: $\mathbf{3 0}$

feet US (US, UB) to 0 feet $\underline{\mathbf{U B}}$ (US, UB, DS)

43. Bank damage: 1

(1- eroded and/or creep; 2- slip failure; 3- block failure)

44. Cut bank comments (eg. additional cut banks, protection condition, etc.):

45. Is channel scour present? $\mathbf{N}$ ( $Y$ or if $N$ type ctrl-n cs)

47. Scour dimensions: Length Width Depth : 46. Mid-scour distance: -

48. Scour comments (eg. additional scour areas, local scouring process, etc.):

NO CHANNEL SCOUR

The middle of the scour hole is under the bridge and it is described in the under bridge channel assessment section.

\section{Are there major confluences? $\mathbf{N}$} (Y or if $N$ type ctrl-n mc)

51. Confluence 1: Distance 52. Enters on (LB or $R B)$ Confluence 2: Distance Enters on (LB or $R B)$

54. Confluence comments (eg. confluence name):

NO MAJOR CONFLUENCES

The minor inflow on the left bank is not presently flowing.
50. How many? -

53. Type(1-perennial; 2- ephemeral)

Type (1-perennial; 2-ephemeral)

\section{Under Bridge Channel Assessment}

55. Channel restraint (BF)? LB 2

56. Height (BF)
LB RB
22.5
58. Bank width (BF) -
59. Channel width (Amb) (1- natural bank; 2- abutment; 3- artificial levee)

Bed and bank Material: 0- organics; 1- silt / clay, < 1/16mm; 2- sand, 1/16 - 2mm; 3- gravel, 2 - 64mm; 4- cobble, 64 - 256mm; 5- boulder, > 256mm; 6- bedrock; 7- manmade

Bank Erosion: 0- not evident; 1- light fluvial; 2- moderate fluvial; 3- heavy fluvial / mass wasting

64. Comments (bank material variation, minor inflows, protection extent, etc.):

05

Some boulders are at the US end of the scour hole. Twigs and leaves have accumulated along the abutments below the water surface. 
65. Debris and Ice Is there debris accumulation?

(Yor $N)$ 66. Where? $\underline{Y}$

(1- Upstream; 2- At bridge; 3- Both)

67. Debris Potential $\underline{3}$

( 1- Low; 2- Moderate; 3- High)

68. Capture Efficiency 2

(1- Low; 2- Moderate; 3- High)

69. Is there evidence of ice build-up? 2

Ice Blockage Potential $\mathbf{N}$

(1-Low; 2- Moderate; 3- High)

70. Debris and Ice Comments:

2

The bridge constricts and the low chord is not very high so at high flows debris and ice will get caught.

There are some twigs caught in the I-beams.

\begin{tabular}{|l|c|c|c|c|c|c|c|c|}
\hline Abutments & $\begin{array}{c}71 . \text { Attack } \\
\angle \text { (BF) }\end{array}$ & $\begin{array}{c}72 \text {. Slope } \angle \\
\text { (Qmax) }\end{array}$ & $\begin{array}{c}\text { 73. Toe } \\
\text { loc. (BF) }\end{array}$ & $\begin{array}{c}\text { 74. Scour } \\
\text { Condition }\end{array}$ & $\begin{array}{c}75 . \text { Scour } \\
\text { depth }\end{array}$ & $\begin{array}{c}\text { 76. Exposure } \\
\text { depth }\end{array}$ & 77. Material & 78. Length \\
\hline LABUT & & $\mathbf{2 0}$ & $\mathbf{9 0}$ & $\mathbf{2}$ & $\mathbf{3}$ & $\mathbf{2}$ & $\mathbf{2}$ & $\mathbf{9 0 . 0}$ \\
\hline RABUT & $\mathbf{1}$ & - & $\mathbf{9 0}$ & & & $\mathbf{2}$ & $\mathbf{2}$ & $\mathbf{1 9 . 5}$ \\
\hline
\end{tabular}

Pushed: $L B$ or RB

Toe Location (Loc.): 0- even, 1- set back, 2- protrudes

Scour cond.: 0- not evident; 1- evident (comment); 2- footing exposed; 3-undermined footing; 4- piling exposed; 5- settled; 6- failed

Materials: 1- Concrete; 2- Stone masonry or drywall; 3- steel or metal; 4- wood

79. Abutment comments (eg. undermined penetration, unusual scour processes, debris, etc.):

0

1

1

There is a scour hole that is continuous from 30 feet US of the bridge to 10 feet DS of the bridge. The bridge constricts the main channel flow upstream where several tributaries enter. The hole is 60 feet long, 16 feet wide, and the maximum depth is 3 feet below the average thalweg depth elsewhere in the reach.

80. Wingwalls:

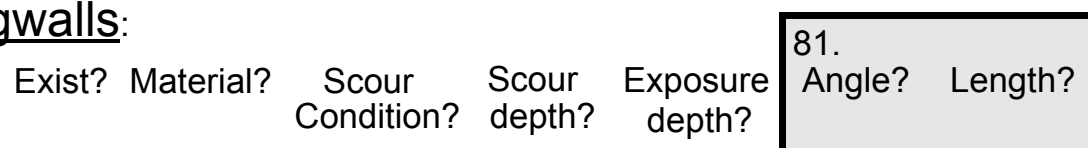

USLWW:

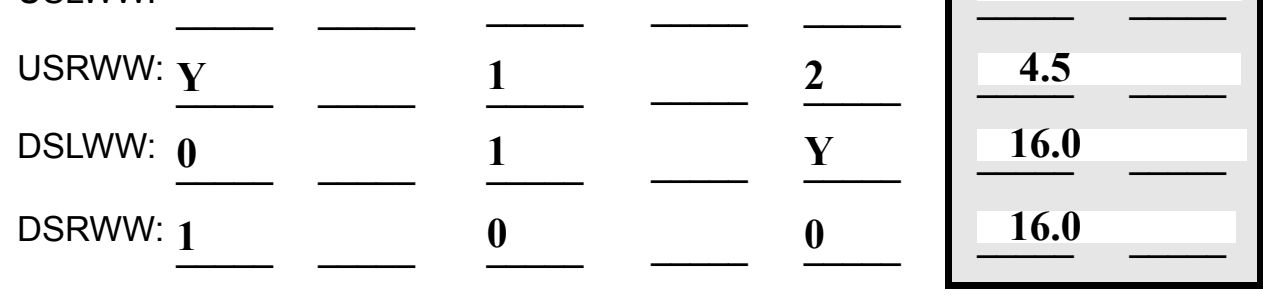

Wingwall materials: 1- Concrete; 2- Stone masonry or drywall; 3- steel or metal; 4- wood

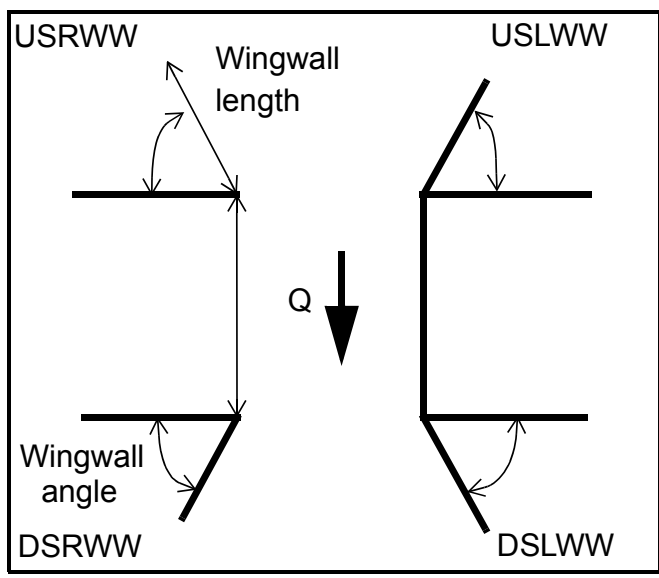

82. Bank / Bridge Protection:

\begin{tabular}{|l|l|l|l|l|l|l|c|c|}
\hline Location & USLWW & USRWW & LABUT & RABUT & LB & RB & DSLWW & DSRWW \\
\hline Type & - & $\mathbf{2}$ & Y & $\mathbf{0}$ & - & - & - & - \\
\hline Condition & $\mathbf{Y}$ & $\mathbf{0}$ & $\mathbf{1}$ & - & - & - & - & - \\
\hline Extent & $\mathbf{1}$ & $\mathbf{0 . 2}$ & $\mathbf{0}$ & $\mathbf{0}$ & $\mathbf{0}$ & $\mathbf{0}$ & $\mathbf{0}$ & - \\
\hline
\end{tabular}

Bank / Bridge protection types: 0- absent; 1- < 12 inches; 2- < 36 inches; 3- < 48 inches; 4- < 60 inches; 
83. Wingwall and protection comments (eg. undermined penetration, unusual scour processes, etc.):

$-$

$-$

$-$

$-$

$-$

0

$-$

0

0

\section{Piers:}

84. Are there piers? Th (Y or if $N$ type ctrl-n pr)

\begin{tabular}{|l|c|c|c|c|c|c|c|}
\hline $\begin{array}{l}85 . \\
\text { Pier no. }\end{array}$ & \multicolumn{3}{|c|}{ width (w) feet } & \multicolumn{3}{|c|}{ elevation (e) feet } \\
\cline { 2 - 8 } & w1 & w2 & w3 & e@w1 & e@w2 & e@w3 \\
\hline Pier 1 & & & & $\mathbf{6 0 . 0}$ & $\mathbf{1 0 . 5}$ & $\mathbf{6 0 . 0}$ \\
\hline Pier 2 & & & $\mathbf{6 . 0}$ & $\mathbf{1 0 . 5}$ & $\mathbf{4 0 . 0}$ & $\mathbf{4 0 . 0}$ \\
\hline Pier 3 & $\mathbf{8 . 5}$ & - & - & - & - & - \\
\hline Pier 4 & - & - & - & - & - & - & w1 \\
\hline
\end{tabular}

\begin{tabular}{|l|l|l|l|l|}
\hline Level 1 Pier Descr. & \multicolumn{1}{|c|}{1} & \multicolumn{1}{|c|}{2} & \multicolumn{1}{|c|}{3} & 4 \\
\hline 86. Location (BF) & e US & along & & - \\
\hline 87. Type & left & the & N & - \\
\hline 88. Material & wing & base. & - & - \\
\hline 89. Shape & wall & & - & - \\
\hline 90. Inclined? & has & & - & - \\
\hline 91. Attack $\angle$ (BF) & an & & - & - \\
\hline 92. Pushed & accu & & - & - \\
\hline 93. Length (feet) & - & - & - & - \\
\hline 94. \# of piles & mula & & - & - \\
\hline 95. Cross-members & tion & & - & - \\
\hline 96. Scour Condition & of & & - & - \\
\hline 97. Scour depth & boul- & & - & - \\
\hline 98. Exposure depth & ders & & - & - \\
\hline
\end{tabular}

LFP, LTB, LB, MCL, MCM, MCR, RB, RTB, RFP

1- Solid pier, 2-column, 3- bent

1-Wood; 2-concrete; 3- metal; 4- stone

1- Round; 2- Square; 3- Pointed

Y-yes; $N$ - no

$L B$ or $R B$

0- none; 1- laterals; 2- diagonals; 3- both

0- not evident; 1- evident (comment);

2- footing exposed; 3- piling exposed;

4- undermined footing; 5- settled; 6- failed 
99. Pier comments (eg. undermined penetration, protection and protection extent, unusual scour processes, etc.):

-
-
-
-
-
-
-
-
-
-

100.

\section{E. Downstream Channel Assessment}

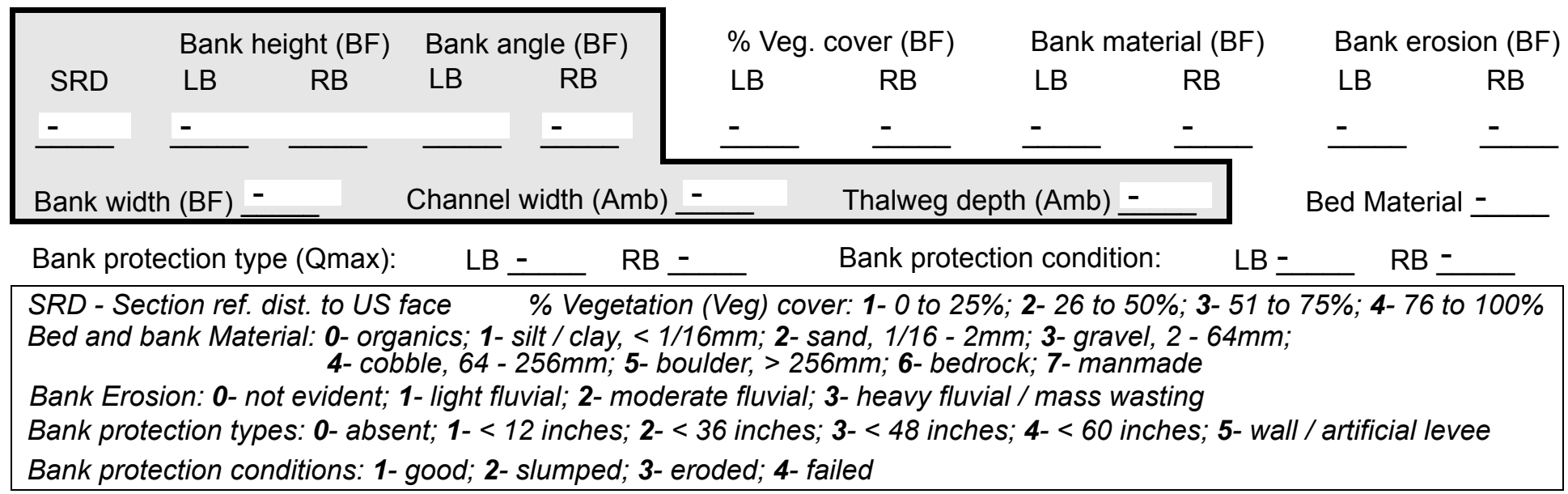

Comments (eg. bank material variation, minor inflows, protection extent, etc.):

-

NO PIERS

101. Is a drop structure present? 1 ( $Y$ or $N$, if $N$ type ctrl-n ds) 102. Distance: ___ feet

103. Drop: -_ feet 104. Structure material: 1 (1- steel sheet pile; 2- wood pile; 3- concrete; 4- other)

105. Drop structure comments (eg. downstream scour depth):

2

2

2

2

32

$\mathbf{0}$ 


\section{Point bar extent: The feet $\underline{\text { hig }}$ (US, UB, DS) to $\underline{\mathbf{h} \text { feet vel }}$ (US, UB, DS) positioned oci \%LB to ty $\%$ RB}

Material: of

Point or side bar comments (Circle Point or Side; note additional bars, material variation, status, etc.):

water going through the bridge opening has transported a large quantity of gravel, which deposited DS of the bridge creating a short section of "braided" stream.

Is a cut-bank present?

Cut bank extent: feet (Y or if $N$ type ctrl-n cb)

Where? (LB or $R B)$ feet (US, UB, DS)

Bank damage: (US, UB, DS) to (1- eroded and/or creep; 2- slip failure; 3- block failure)

Cut bank comments (eg. additional cut banks, protection condition, etc.):

$\mathbf{N}$

Is channel scour present? ( $Y$ or if $N$ type ctrl-n cs)

Mid-scour distance: NO (1) 
108. Evolution comments (Channel evolution not considering bridge effects; See HEC-20, Figure 1 for geomorphic descriptors):

-

NO POINT BARS

Y

LB

22.5

5

DS

40

DS

1 


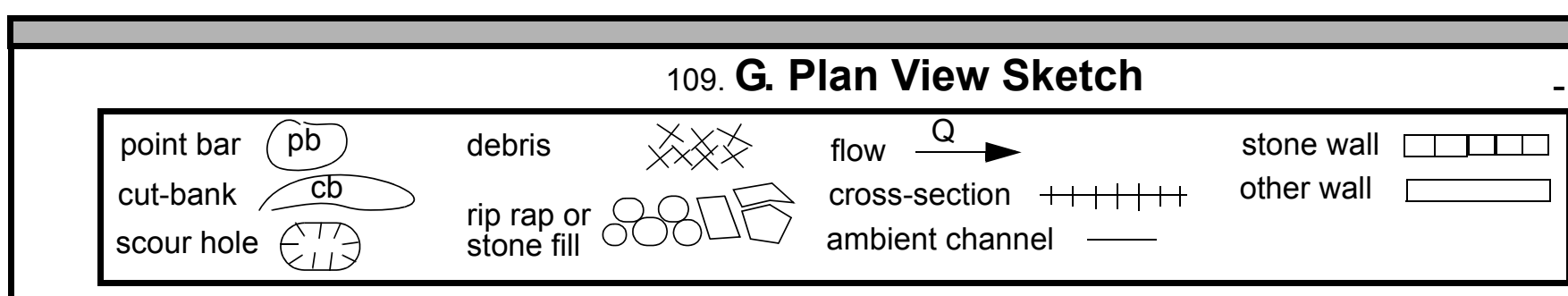

cut-bank $\mathrm{cb}$

scour hole rip rap or
stone fill stone fill cross-section $+1+1+1$ ambient channe other wall 
APPENDIX F:

SCOUR COMPUTATIONS 
SCOUR COMPUTATIONS

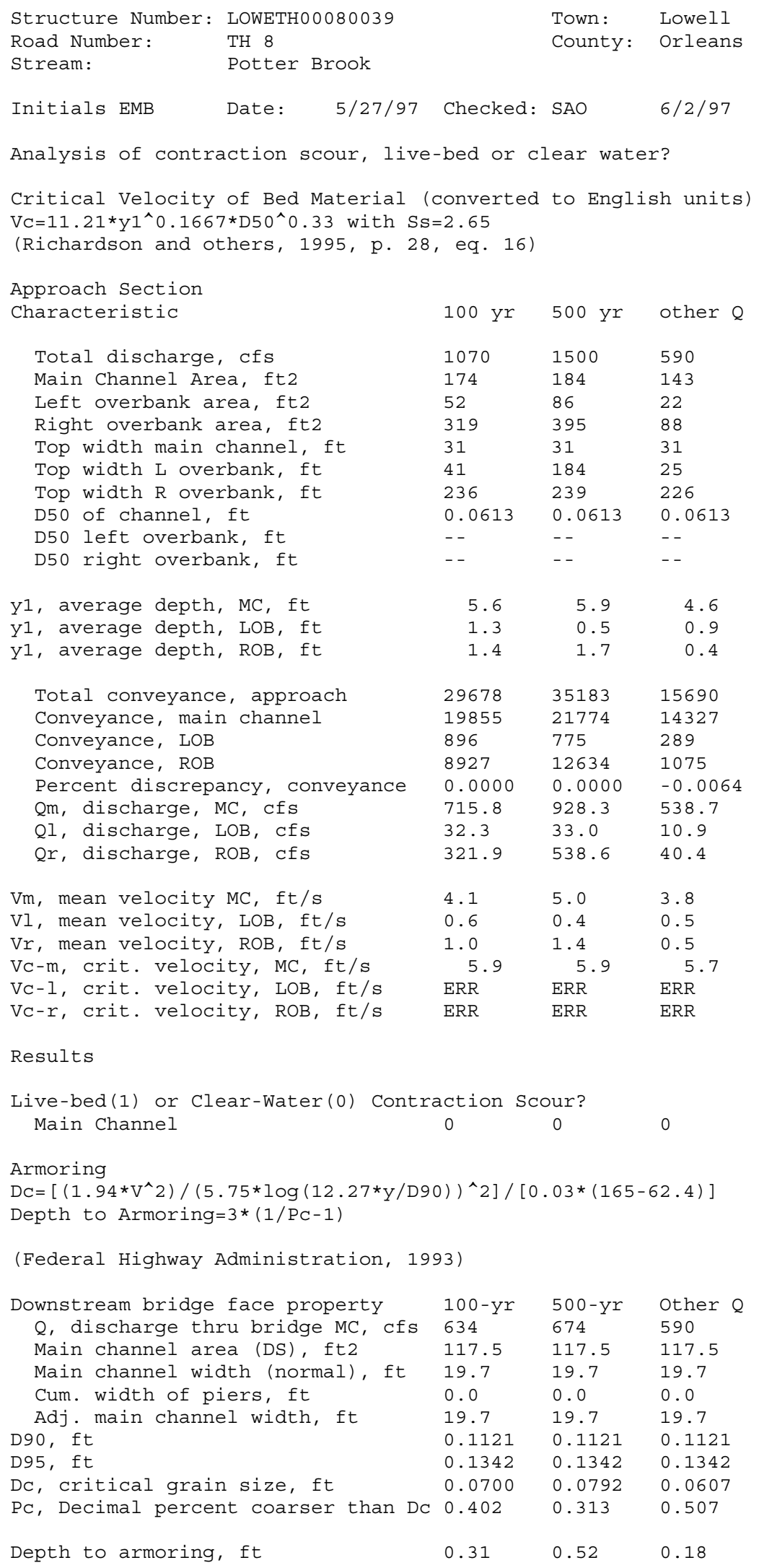


Clear water Contraction Scour in MAIN CHANNEL

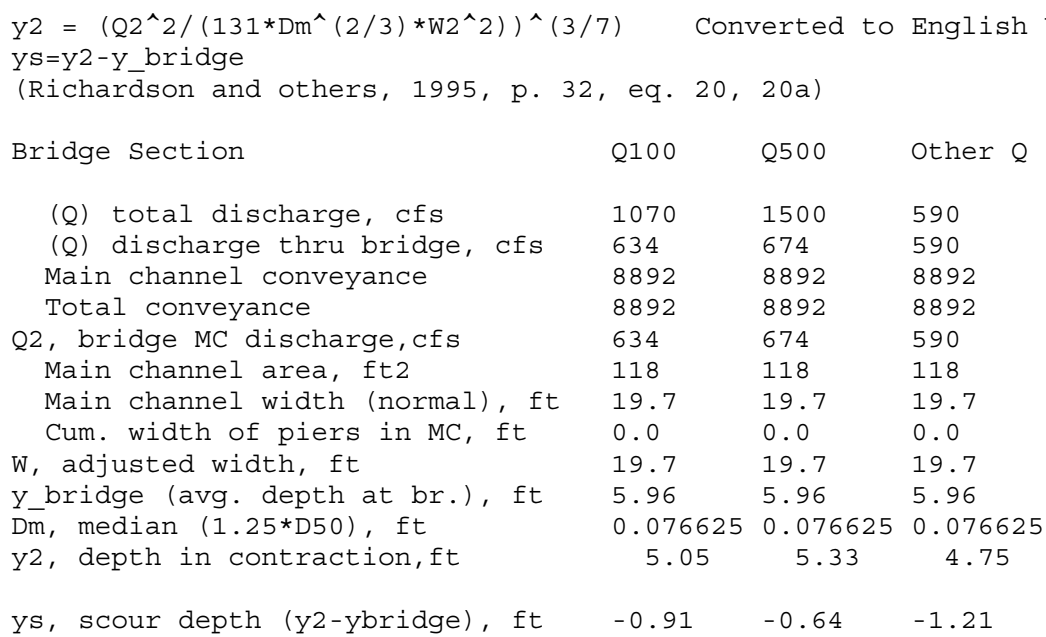

Pressure Flow Scour (contraction scour for orifice flow conditions)

\begin{tabular}{|c|c|c|c|}
\hline $\begin{array}{l}\text { Chang pressure flow equation } \\
\mathrm{Cq}=1 / \mathrm{Cf} * \mathrm{CC} \quad \mathrm{Cf}=1.5 * \mathrm{Fr}^{\wedge} 0.43 \quad(<=1)\end{array}$ & $\begin{array}{l}\mathrm{Hb}+\mathrm{Ys}=\mathrm{C} \\
\mathrm{CC}=\mathrm{SQRT}\end{array}$ & $\begin{array}{l}q b r / V c \\
.10(\mathrm{Hb}\end{array}$ & \\
\hline $\begin{array}{l}\text { Umbrell pressure flow equation } \\
(\mathrm{Hb}+\mathrm{Ys}) / \mathrm{ya}=1.1021 *[(1-\mathrm{w} / \mathrm{ya}) *(\mathrm{Va} / \mathrm{VC}) \\
\text { (Richardson and other, 1995, p. } 144\end{array}$ & & & \\
\hline & Q100 & Q500 & Other \\
\hline Q, total, cfs & 1070 & 1500 & 590 \\
\hline Q, thru bridge $\mathrm{MC}$, Cfs & 634 & 674 & 59 \\
\hline Vc, critical velocity, ft/s & 5.89 & 5.95 & 5.70 \\
\hline Va, velocity MC approach, ft/s & 4.11 & 5.05 & 3.77 \\
\hline Main channel width (normal), ft & 19.7 & 19.7 & .7 \\
\hline Cum. width of piers in MC, ft & 0.0 & 0.0 & 0 . \\
\hline W, adjusted width, ft & 19.7 & 19.7 & 19.7 \\
\hline qbr, unit discharge, ft2/s & 32.2 & 34.2 & 29.9 \\
\hline Area of full opening, ft2 & 117.5 & 117.5 & 117.5 \\
\hline Hb, depth of full opening, ft & 5.96 & 5.96 & 5.96 \\
\hline Fr, Froude number, bridge MC & 0.39 & 0.41 & 0.36 \\
\hline Cf, Fr correction factor $(<=1.0)$ & 1.00 & 1.00 & 0.97 \\
\hline **Area at downstream face, ft 2 & $\mathrm{~N} / \mathrm{A}$ & $\mathrm{N} / \mathrm{A}$ & $\mathrm{N} /$ \\
\hline **Hb, depth at downstream face, ft & $\mathrm{N} / \mathrm{A}$ & $\mathrm{N} / \mathrm{A}$ & $\mathrm{N} / \mathrm{A}$ \\
\hline **Fr, Froude number at DS face & ERR & ERR & ERR \\
\hline **Cf, for downstream face $(<=1.0)$ & $\mathrm{N} / \mathrm{A}$ & $\mathrm{N} / \mathrm{A}$ & \\
\hline Elevation of Low Steel, ft & 497.92 & 497.92 & 7.9 \\
\hline Elevation of Bed, ft & 491.96 & 491.96 & L.. \\
\hline Elevation of Approach, ft & 499.82 & 500.14 & 498.82 \\
\hline Friction loss, approach, ft & 0.08 & 0.12 & 0.06 \\
\hline Elevation of WS immediately US, ft & 499.74 & 500.02 & 498.7 \\
\hline ya, depth immediately us, ft & 7.78 & 8.06 & 6.80 \\
\hline Mean elevation of deck, ft & 500.1 & 500.1 & 500.1 \\
\hline w, depth of overflow, ft $(>=0)$ & 0.00 & 0.00 & 0.00 \\
\hline Cc, vert contrac correction $(<=1.0)$ & 0.93 & 0.92 & 0.97 \\
\hline$* * \mathrm{Cc}$, for downstream face $(<=1.0)$ & ERR & ERR & ERR \\
\hline scour w/Chang equation, ft & -0.11 & 0.26 & -0.35 \\
\hline scour w/Umbrell equation, ft & 0.94 & 2.08 & -0.12 \\
\hline
\end{tabular}

**=for UNsubmerged orifice flow using estimated downstream bridge face properties.

**Ys, scour w/Chang equation, ft $\mathrm{N} / \mathrm{A} \quad \mathrm{N} / \mathrm{A} \quad \mathrm{N} / \mathrm{A}$

**Ys, scour w/Umbrell equation, ft N/A N/A N/A

In UNsubmerged orifice flow, an adjusted scour depth using the Laursen equation results and the estimated downstream bridge face properties can also be computed (ys=y2-ybridgeDs)

$\begin{array}{llll}\text { Y2, from Laursen's equation, ft } & 5.05 & 5.33 & 4.75 \\ \text { WSEL at downstream face, ft } & -- & -- & -- \\ \text { Depth at downstream face, ft } & \text { N/A } & \text { N/A } & \text { N/A } \\ \text { depth of scour (Laursen), ft } & \text { N/A } & \text { N/A } & \text { N/A }\end{array}$

Ys, depth of scour (Laursen), ft N/A N/A N/A 


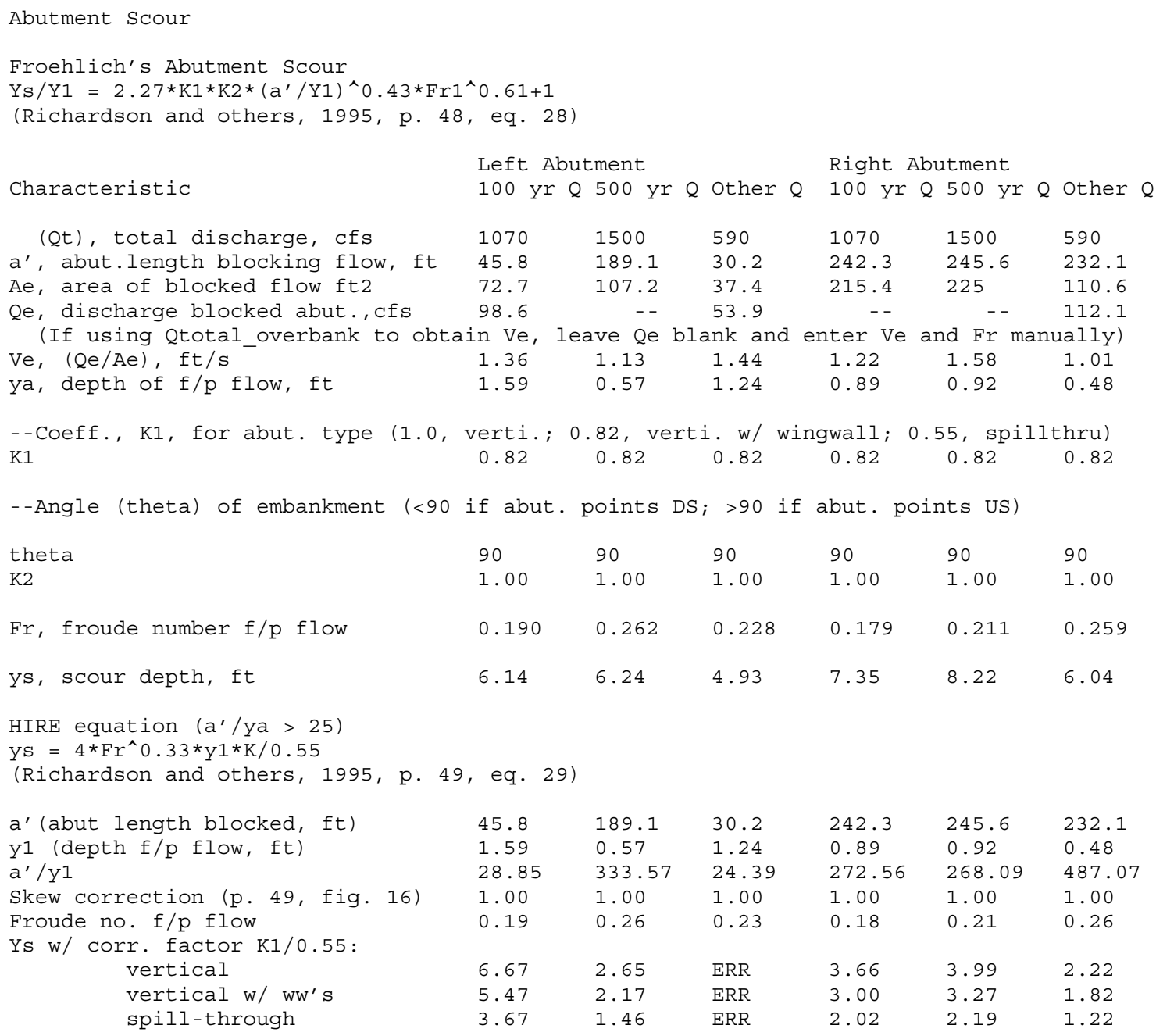

The ratio of $\mathrm{a}^{\prime} / \mathrm{y} 1$ was set to 25.00 from 24.39 to force computation of abutment scour for the incipient discharge at the left abutment.

Abutment riprap Sizing

Isbash Relationship

$\mathrm{D} 50=\mathrm{Y} * \mathrm{~K} * \mathrm{Fr} \wedge 2 /(\mathrm{Ss}-1)$ and $\mathrm{D} 50=\mathrm{Y} * \mathrm{~K} *\left(\mathrm{Fr}^{\wedge} 2\right)^{\wedge} 0.14 /(\mathrm{Ss}-1)$

(Richardson and others, 1995, p112, eq. 81,82)

Downstream bridge face property

Q100 Q500

Other Q Q100

Q500

Other Q

Fr, Froude Number

$0.39 \quad 0.41$

0.36

0.39

0.41

0.36

$y$, depth of flow in bridge, ft

5.96

5.96

5.96

5.96

$5.96 \quad 5.96$

Median Stone Diameter for riprap at: left abutment

right abutment, ft

$\begin{array}{llllllll}\text { Fr<=0.8 } & \text { (vertical abut.) } & 0.56 & 0.62 & 0.48 & 0.56 & 0.62 & 0.48 \\ \text { Fr }>0.8 & \text { (vertical abut.) } & \text { ERR } & \text { ERR } & \text { ERR } & \text { ERR } & \text { ERR } & \text { ERR }\end{array}$

